\title{
Tank 16 Annulus Cleanout Analysis Doses at Seepline from Transport of Residual TC-99 Wastes
}

by

L. B. Collard

Westinghouse Savannah River Company

Savannah River Site

Aiken, South Carolina 29808

DOE Contract No. DE-AC09-96SR18500

This paper was prepared in connection with work done under the above contract number with the U.S.

Department of Energy. By acceptance of this paper, the publisher and/or recipient acknowledges the U. S. Government's right to retain a nonexclusive, royalty-free license in and to any copyright covering this paper, along with the right to reproduce and to authorize others to reproduce all or part of the copyrighted paper. 


\section{DISCLAIMER}

This report was prepared as an account of work sponsored by an agency of the United States Government. Neither the United States Government nor any agency thereof, nor any of their employees, makes any warranty, express or implied, or assumes any legal liability or responsibility for the accuracy, completeness, or usefulness of any information, apparatus, product, or process disclosed, or represents that its use would not infringe privately owned rights. Reference herein to any specific commercial product, process, or service by trade name, trademark, manufacturer, or otherwise does not necessarily constitute or imply its endorsement, recommendation, or favoring by the United States Government or any agency thereof. The views and opinions of authors expressed herein do not necessarily state or reflect those of the United States Government or any agency thereof.

This report has been reproduced directly from the best available copy.

Available to DOE and DOE contractors from the Office of Scientific and Technical Information, P.O. Box 62, Oak Ridge, TN 37831; prices available from (615) 576-8401.

Available to the public from the National Technical Information Service, U.S. Department of Commerce; 5285 Port Royal Road, Springfield, VA 22161. 


\section{DISCLAIMER}

Portions of this document may be illegible in electronic image products. Images are produced from the best available original document. 
KEYWORDS: RADIOLOGICAL DOSE

Tc-99

TANK 16 WASTE

RETENTION: Permanent

TANK 16 ANNULUS CLEANOUT ANALYSIS

DOSES AT SEEPLINE FROM TRANSPORT OF RESIDUAL TC-99 WASTES (U)

Author

Leonard B. Collard

Westinghouse Savannah River Company Savannah River Site Aiken, SC 29808

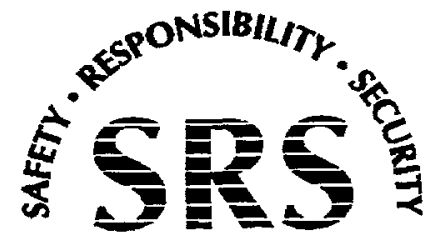


WSRC-TR-99-00004

JANUARY 19, 1999

TANK 16 ANNULUS CLEANOUT ANALYSIS

DOSES AT SEEPLINE FROM TRANSPORT OF RESIDUAL TC-99 WASTES

Author
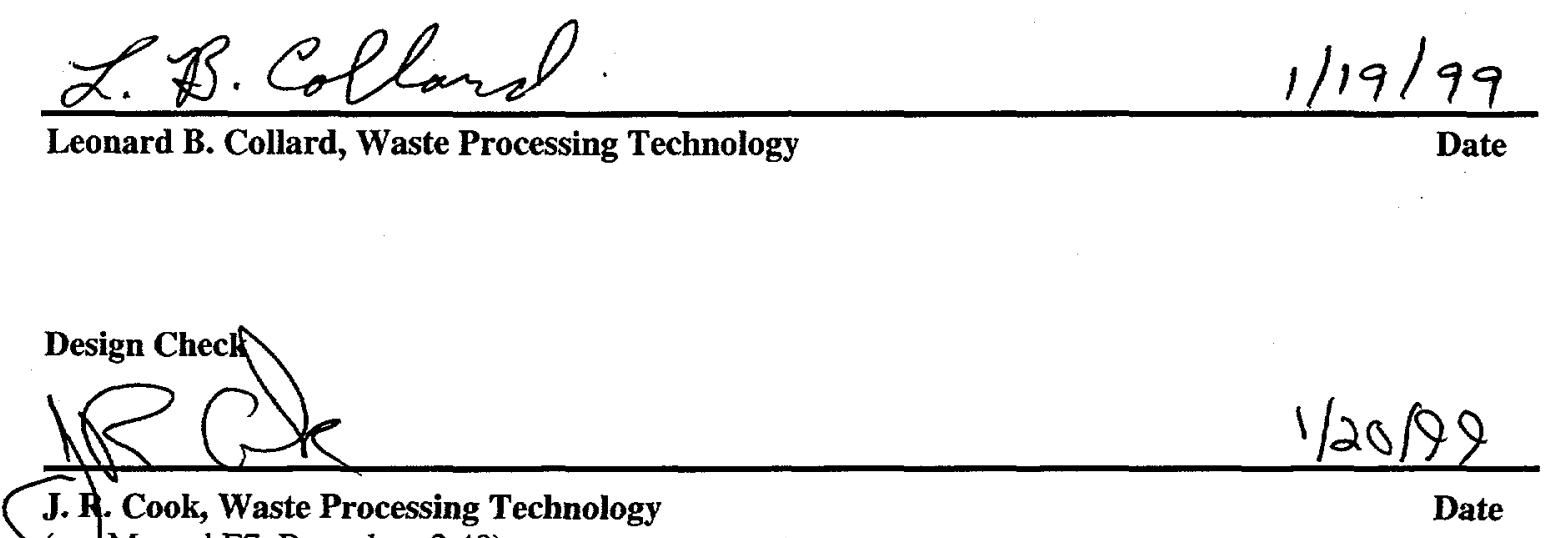

Approvals/Review
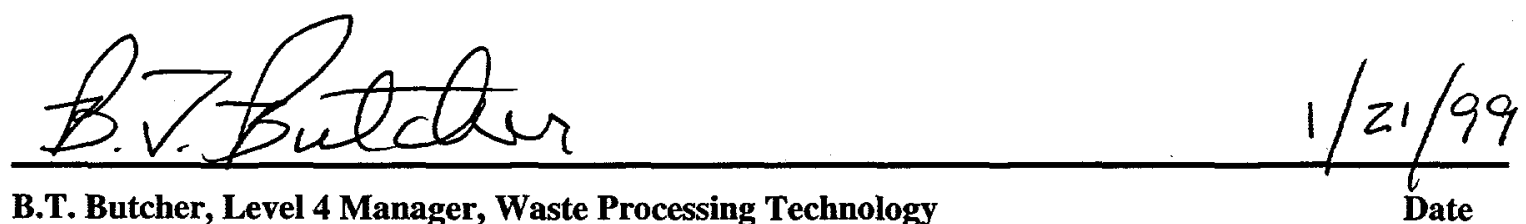

ii 
B. T. Butcher, 773-43A

DISTRIBUTION

T. B. Caldwell, 742-4G

L. B. Collard, 773-43A

J. R. Cook, 773-43A

P. D. d'Entremont, 703-H

T. S. Gutmann, 704-S

T. Hang, 773-43A

G. R. Hannah, Jr., 703-H

L. T. Ling, 703-H

B. A. Martin, $742-4 \mathrm{G}$

T. M. Monahon, $703 \mathrm{H}$

J. P. Morin, 703-H

J. L. Newman, 703-H

E. Saldivar, 742-4G

W. E. Stevens, 773-A

E. L. Wilhite, 773-43A

STI (4)

WPT File 


\section{TABLE OF CONTENTS}

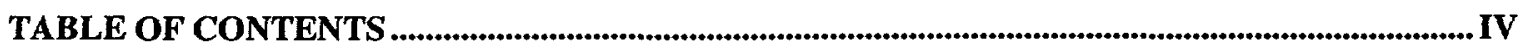

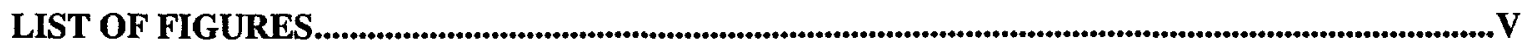

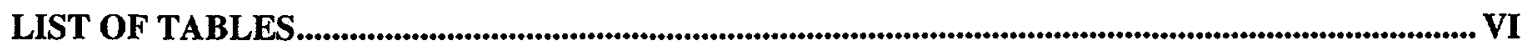

1. INTRODUCTION

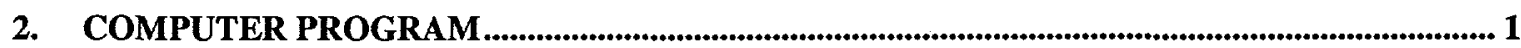

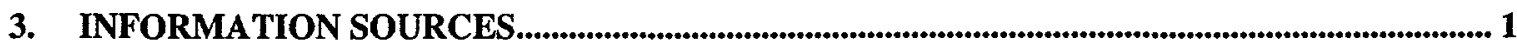

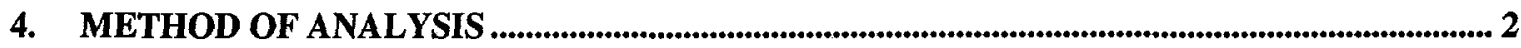

4.1. Contaminant Inventories and Decay Rates .................................................................................... 2

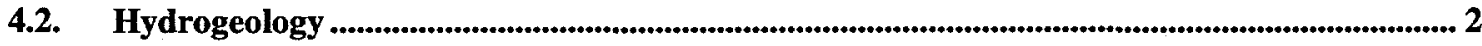

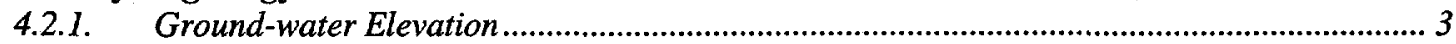

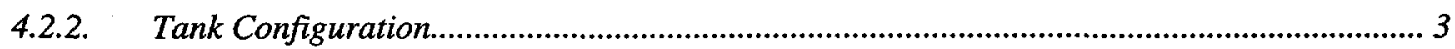

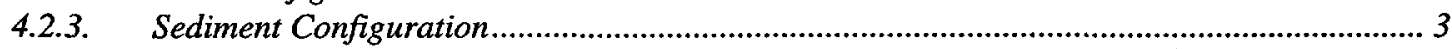

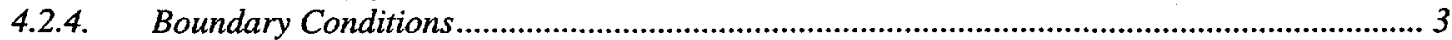

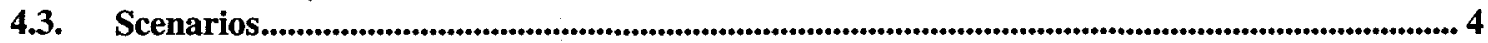

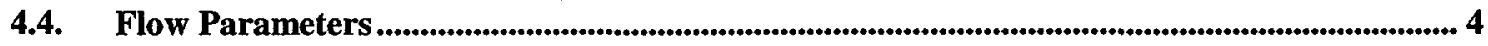

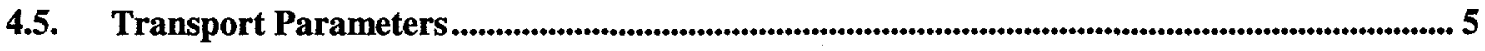

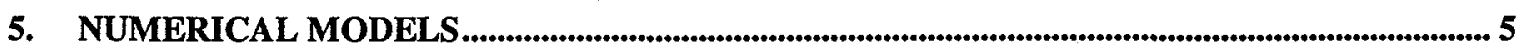

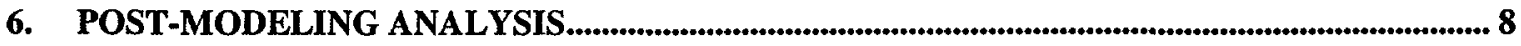

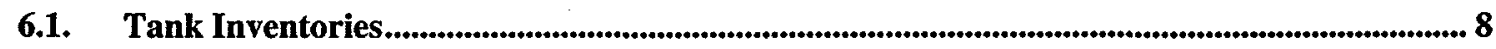

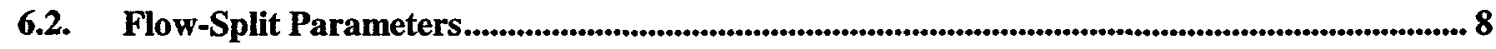

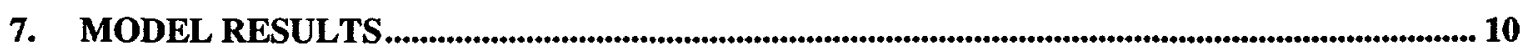

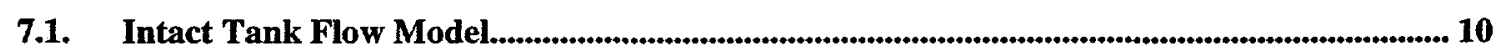

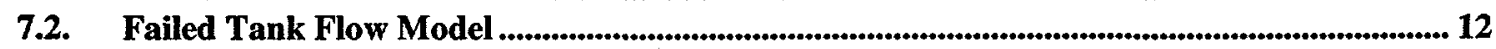

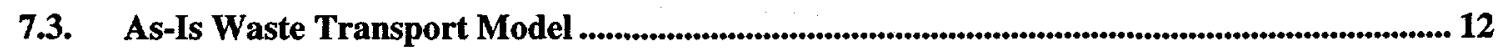

7.4. Cleaned Waste Transport Model ......................................................................................... 19

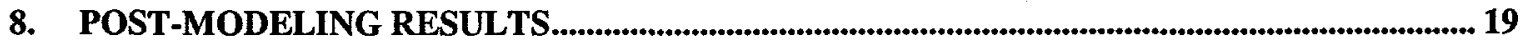

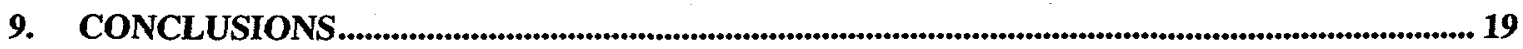

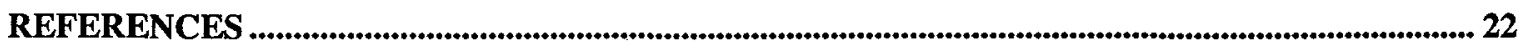

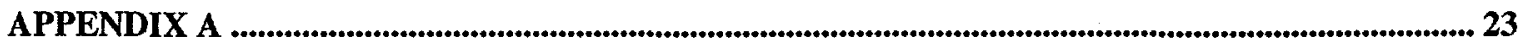




\section{LIST OF FIGURES}

Figure 1. Total Mesh 6

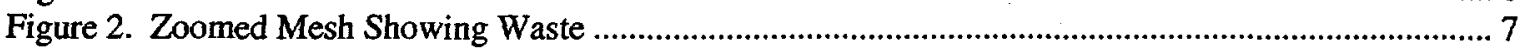

Figure 3. Flow Splits Between Aquifers.................................................................................................. 9

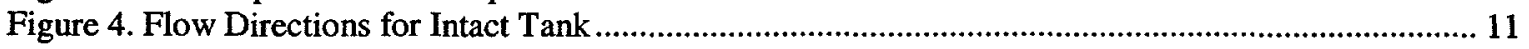

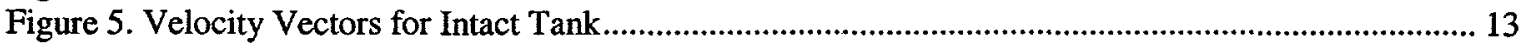

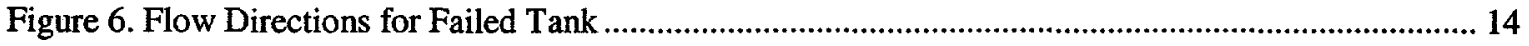

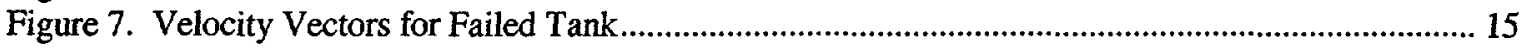

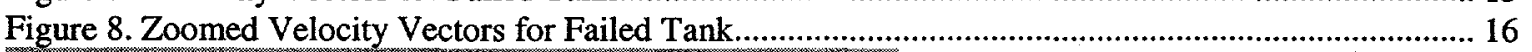

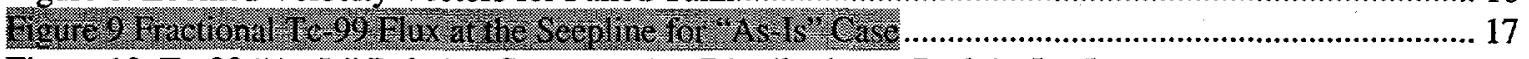

Figure 10. Tc-99 "As-Is" Relative Concentration Distribution at Peak in 5175 .......................................... 18

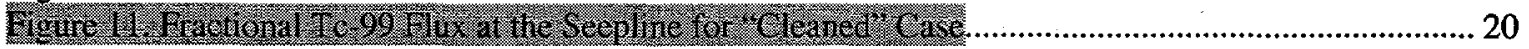

Figure 12. Tc-99 "Cleaned" Relative Concentration Distribution at Peak in 6173 ...................................... 21 


\section{LIST OF TABLES}

Table 1. Tc-99 Inventory Data from Tank 16 Samples ................................................................................. 8

Table 2. Contaminant Flux from an Aquifer to a Seepline (\%) .................................................................. 10

Table 3. Peak Tc-99 Doses at Seepline ……............................................................................................. 19

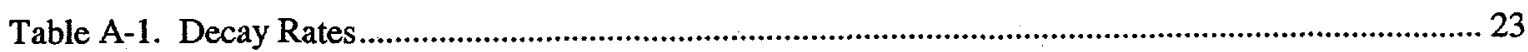

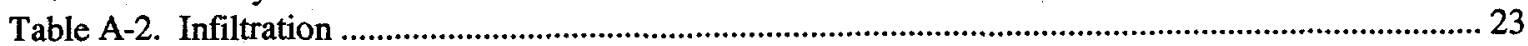

Table A-3. Unsaturated Zone Information ............................................................................................. 25

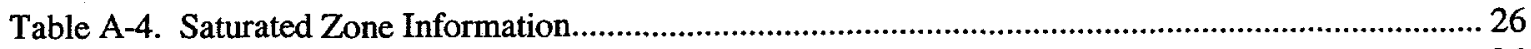

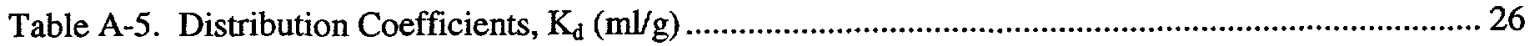

Table A-6. Post-Modeling Worksheet for As-Is Scenario ......................................................................... 27

Table A-7. Post-Modeling Worksheet for Cleaned Scenario ..................................................................... 28 


\section{EXECUTIVE SUMMARY}

An analysis of residual Tc-99 in the Tank 16 annulus was conducted to assess the potential benefit from cleaning the annulus. One analysis was performed for the as-is case to determine seepline doses if no clean out occurs. Another analysis was performed assuming that ninety percent of existing contaminants are removed.

Characterization data for samples retrieved from the annulus were used in the analysis. The sample with the highest Tc-99 concentration of less than $0.40 \mu \mathrm{Ci} / \mathrm{g}$ was selected by High Level Waste (HLW) for use in the model. HLW provided an estimate of 22,000 pounds of waste currently in the annulus.

Model results at the seepline indicate that the Tc-99 peak dose is about $2.9 \mathrm{mrem} / \mathrm{yr}$ at 5,175 years for the current annulus inventory (the "As-Is" case). That peak dose is slightly below the regulatory limit of 4 $\mathrm{mrem} / \mathrm{yr}$. If 90 percent of the waste is removed by reducing the height of the waste (the "Cleaned" case), the peak seepline dose would be reduced to $0.32 \mathrm{mrem} / \mathrm{yr}$ at 6,173 years. Removing 90 percent of the waste delays the peak for about 1,000 years, although each curve closely approaches its peak by 2,000 years.

Only Tc- 99 was analyzed, because preliminary modeling identified it as the highest dose contributor. The effect of residual waste in piping was not analyzed. 


\section{INTRODUCTION}

An analysis of residual Tc- 99 in the Tank 16 annulus was conducted to assess the potential benefit from cleaning the annulus. One analysis was performed for the as-is case to determine seepline doses if no clean out occurs. Another analysis was performed assuming that ninety percent of existing contaminants are removed.

The contaminant transport analyses incorporate a computer program and several information sources. The computer program models contaminant transport through the subsurface to the seepline. Information sources developed to support earlier modeling efforts are used as inputs to the computer program. New Tc99 characterization data from the Tank 16 annulus supplement earlier information.

\section{COMPUTER PROGRAM}

The PORFLOWO (ACRi, 1998) computer program predicted transport of contaminants to the seepline. The PORFLOW program is numerical analysis software for modeling ground-water flow and contaminant transport through the subsurface. PORFLOW can accommodate multiple chemical species, radioactive decay chains, transient and steady-state flow conditions, saturated and unsaturated media, multiple material types, and one, two or three dimensional geometries of any shape. State and federal regulators throughout the United States have accepted PORFLOW results for similar applications (Collard, 1998)

\section{INFORMATION SOURCES}

A simplified two-dimensional model was developed and input to the PORFLOW program. Information required by the model included the following:

- Contaminant inventories and decay rates

- Hydrogeology including natural and man-made features

- Elevation of water table relative to inside tank base

- Tank configuration

- Contaminant properties

- Boundary conditions

- Thicknesses of material layers

- Unsaturated and saturated zone inputs for each material type

- Ground-water flow properties

- Contaminant transport properties.

Values copied from or derived from the information sources are presented in tables in Appendix A.

Contaminant inventories were developed from sample characterization data (Hay, 1999) and estimates of the total amount of residual waste provided by HLW. Contaminant decay rates were obtained from the Tank 20 analysis (DOE, 1997).

Hydrogeologic information was gleaned from many sources. Ground-water elevation data were selected from the GIMS on-line database. Engineering drawings were read to determine the elevation of the tanks. Contaminant properties, boundary conditions, and aquifer thicknesses were obtained from the Tank 20 analysis (DOE, 1997).

Unsaturated and saturated zone material properties included ground-water flow properties and contaminant transport properties. The material properties were obtained from the Tank 20 analysis (DOE, 1997), the Fand H-Area closure plan (DOE, 1996), and Freeze and Cherry (1979). 


\section{METHOD OF ANALYSIS}

The first step in the analysis was to define conceptual models. The conceptual models included several topics as follows:

1) Contaminant Inventories and Decay Rates

2) Hydrogeology

3) Scenarios

4) Flow Parameters

5) Transport Parameters

6) Tank Inventories

7) Flow-Split Parameters.

The first five topics are discussed in Sections 4.1 through 4.5. The last two topics, tank inventories and flow-split parameters, were addressed after the computer modeling was completed in the post-modeling analysis.

For each conceptual model, input parameters were assigned to generate a numerical model discussed in Section 5. After the numerical model was generated, the PORFLOW computer program was executed to analyze the model.

After each numerical model was analyzed, post-modeling analysis was performed to calculate final results. The steps in the post-modeling analysis are as follow:

(a) Combine contaminant fluxes with water fluxes to calculate average seepline discharge concentrations. These concentrations are developed and expressed as fractions of the original tank inventory, rather than as absolute quantities.

(b) Multiply fractional concentrations by tank inventories to calculate absolute concentrations.

(c) Multiply absolute concentrations by flow-splitting factors to generate final analysis results.

The post-modeling analyses are discussed in Section 6.

\subsection{Contaminant Inventories and Decay Rates}

The conceptual model included a contaminant inventory for the annulus only. One curie of Tc-99 was used in the model to provide a fractional basis for post-modeling analysis. Model results were expressed as fractional concentrations, fluxes and doses - relative to the unit curie inventory. Multiplying model results by tank inventories (predicted from the characterization data) and adjusting for aquifer splits produced the absolute doses.

For the two-dimensional, vertical slice through the tank, the contaminant source was uniformly spread across the tank diameter at a depth of six inches. For the cleaned scenario, the lateral extent remained constant, but the depth was reduced to 0.6 inches.

The radioactive decay rate is input in the form of a half-life. The half-life for Tc- 99 is presented in Table A.1.

\subsection{Hydrogeology}

The hydrogeology includes the configuration and properties of subsurface materials and the applicable boundary conditions. This section discusses the configuration and the boundary conditions, while the values of the properties are discussed in the subsequent sections. The configuration is subdivided as follows:

- Ground-water elevation 
- Tank configuration

- Sediment configuration.

\subsubsection{Ground-water Elevation}

A careful review of the GIMs database and the engineering drawings showed that the inside base of the tank lies about two feet below the water table. The last 10 years of ground-water elevation data for well HTF6 (90 feet from Tank 16) and HTF7 (85 feet from Tank 16) were selected. Discarding the highest and lowest value for each well because of apparent anomalies, and averaging the remaining values produced elevations of $275.7 \mathrm{ft}$ above mean sea level (AMSL) and 276.2 ft AMSL, respectively. The combined average is $275.9 \mathrm{ft}$ AMSL. Supporting this water table elevation is engineering drawing W163018 from 1955 that shows a maximum ground-water elevation of 275.0-ft AMSL.

The engineering drawing shows the elevation at the inside base of the tank, the floor, is $274.08 \mathrm{ft}$ AMSL. The annulus is slightly lower at $273.96 \mathrm{ft}$ AMSL because it lacks the $1 / 2$ inch thick tank plate and 1 inch of sand. The water table average ( $275.9 \mathrm{ft}$ AMSL) is about 2 feet above the base of Tank 16 annulus residual wastes ( $273.96 \mathrm{ft}$ AMSL). The water table forms the top of the model domain.

\subsubsection{Tank Configuration}

The modeled tank annulus consists of residual waste, grout added to the annulus prior to closing the tank, and the basemat below the tank. The model represents the annulus and its underlying basemat projected onto a two-dimensional vertical plane. The tank walls and columns are not included in the model. The outside diameter of the annulus is ninety feet in the model.

The annulus is modeled only up to the level of the water table. As described in Section 4.1, the residual waste is uniformly spread across the base of the annulus in the model. The grout fills the annulus space above the waste to the water table.

\subsubsection{Sediment Configuration}

Because all the waste is below the level of the water table, the analysis only considered the aquifer. The geology for the aquifer is based on a single material type, composed primarily of sand. Any clay layers along the pathway to the seepline were neglected for the simplified model. The aquifer material occupied the entire model domain outside the tank annulus.

\subsubsection{Boundary Conditions}

Boundary conditions are prescribed separately for ground-water flow versus contaminant transport problems. Input values are described in Sections 4.4 and 4.5 for flow models and transport models, respectively.

For the ground-water flow model, the surface infiltration was neglected for two reasons. First, all the waste in the Tank 16 annulus lies below the water table (see Section 4.2.1). Second, the speed of water moving horizontally in the aquifer is much greater than the speed of water moving vertically downward through the tank in all scenarios described in Section 4.3. Consequently, the upper boundary condition was prescribed as zero vertical flux. This model is slightly unconservative, because it neglects the slower vertical release of contaminants. Section 8 shows that the Tank 16 model results are significantly greater than the Tank 20 model results would be if the same Tc-99 inventory were used for both models, indicating that the effect of neglecting the surface infiltration appears to be slight.

The Tank 20 analysis (DOE, 1997) considered waste above the water table, where infiltration from the surface was the only water that transported wastes to the water table. The infiltration rates from the Tank 20 analysis are presented in Table A. 2 for comparison. 
The base of the model represents the base of the aquifer where minimal vertical movement of water occurs. Hence, a zero vertical flux condition was applied at the lower model boundary. The side boundary conditions were prescribed as constant horizontal water speeds based on the pore velocities presented in Section 4.4. The combination of zero vertical flux and equal horizontal water speeds at the sides produces a horizontal flow field that is only disrupted by the presence of the tank.

For the contaminant transport model, diffusion out of the model domain was not permitted for any of the edges, except one. The exception was the vertical edge where water exited the domain. Immediately outside that boundary, the concentration was set to zero. The effect of these boundary conditions is to maximize the flux of contaminants out of the model domain along the vertical edge where water exited. As described below, this leads to conservative results whereby maximum concentrations and doses at the seepline are calculated.

\subsection{Scenarios}

Two types of scenarios were modeled. The first type addresses the state of the tank and waste structural properties, while the second type addresses the amount of residual waste in the tank.

\section{(a) Tank and Waste Structural Degradation}

The tank and its waste were assumed to survive in an intact state for 1,000 years, based on the Tank 20 analysis. At 1,000 years, the tank, waste, and tank backfill material were assumed to degrade to a failed state instantaneously. As discussed in Section 4.4, the porosity and bulk density were not adjusted, but the hydraulic conductivities were increased by about 6 orders of magnitude. Values for both states are included in the unsaturated zone information, Table A.3.

\section{(b) Residual Waste Scenarios}

Two scenarios were modeled based on different heights of contaminants remaining in the annulus. Each scenario contained identical model assumptions, other than the waste height. The first scenario is the "As-Is" case that represents the conditions if no cleanout of the contaminants is attempted. The second scenario is the "Cleaned" case that represents the conditions if ninety percent of the contaminants from the "As-Is" case are removed. The waste height for each case is as follows:

\begin{tabular}{|c|c|}
\hline Case & $\begin{array}{c}\text { Residual Waste Height } \\
\text { (inches) }\end{array}$ \\
\hline "As-Is" & 6.0 \\
\hline "Cleaned" & 0.6 \\
\hline
\end{tabular}

Each scenario was modeled with a unit tank inventory. Model results for the "As-Is" case were multiplied by the full estimated tank inventory to calculate final concentrations, fluxes, and doses. Model results for the "Cleaned" case were multiplied by ten percent of the full estimated tank inventory to calculate final concentrations, fluxes, and doses.

\subsection{Flow Parameters}

Flow parameters for the aquifer were based on the Tank 20 analysis parameters. Flow parameters were assigned for the intact state and the failed state after 1,000 years.

Flow parameters are included in the unsaturated zone information, Table A.3, and the saturated zone information, Table A.4. Flow parameters include vertical and horizontal hydraulic conductivities, effective porosity, dry bulk density, matrix compressibility, and pore water velocity. 
The pore water velocity was only used to assign boundary conditions. The pore water velocity was multiplied by the effective porosity to convert it to a Darcy velocity that became the prescribed flow boundary condition along the vertical edges of the model domain.

The porosity and density for the tank and waste were assigned the average of the intact and failed states to preserve mass balance. A closer approximation to the Tank 20 approach could be obtained by making two separate PORFLOW runs and writing an auxiliary program to calculate the contaminant split between the soil and the liquid for both states. This more rigorous approach was not pursued, because of the following:

(a) Model results are not expected to be highly sensitive to changes in porosity and density.

(b) High uncertainty of characterization data and estimates of the amount and types of residual waste are expected to be more significant.

(c) Other significant simplifying assumptions are already incorporated into the model, such as reducing the three-dimensional, three aquifer system to a two-dimensional, single aquifer system.

\subsection{Transport Parameters}

Transport parameters for the aquifer were based on the Tank 20 analysis parameters. Clay layers were ignored, resulting in slightly more conservative results, because Tc-99 is slightly more retarded by clay with a $\mathrm{kd}$ of $1 \mathrm{ml} / \mathrm{g}$ than by sand with a $\mathrm{kd}$ of $0.36 \mathrm{ml} / \mathrm{g}$.

Some transport parameters are included in the unsaturated zone information, Table A.3, and the saturated zone information, Table A.4. Transport parameters from those tables include dry bulk density, dispersion, and total porosity.

The inventory and decay rate affect the fate and transport of Tc-99 and are discussed in Section 4.1. The distribution coefficient is a contaminant-specific property that describes the partitioning of the contaminant between the solids and the water. Distribution coefficients, $\mathrm{K}_{\mathrm{d}} \mathrm{s}$, are presented in Table A.5.

The ground-water flow provides a driving force to move the contaminants through the subsurface. The flow analyses provide fluxes and saturations required for the transport analysis.

\section{NUMERICAL MODELS}

Numerical models are developed from conceptual models. A discretization of the model domain produces a mesh of individual cells that represents the geometries. Each individual cell is assigned flow or transport parameters and boundary conditions are applied to the edges of the model domain to complete the numerical models. For the transport models, some results from the flow models are also required as inputs.

The four different conceptual model scenarios were used to create two numerical flow models and two numerical transport models. The structural degradation scenarios produced one flow model for the intact tank and a second flow model for the failed tank. The tank annulus waste height scenarios produced two transport models, the "As-Is" model and the "Cleaned" model.

The meshes for all numerical models are identical, because the geometries do not change. Figure 1 shows the mesh for the entire model domain with tank and non-tank materials identified. Figure 2 provides a zoomed in picture of the mesh for the tank with residual waste regions highlighted for the "As-Is" case and the "Cleaned" case.

After assigning flow parameters, each flow model was exercised until steady-state conditions were attained. The intact flow model was used for the first 1,000 years of transport analysis, while the failed state flow model was used for all transport beyond 1,000 years.

After executing the numerical flow models, the steady-state saturations and fluxes were combined with the transport parameters to produce the numerical transport models. The transport models were executed in a 


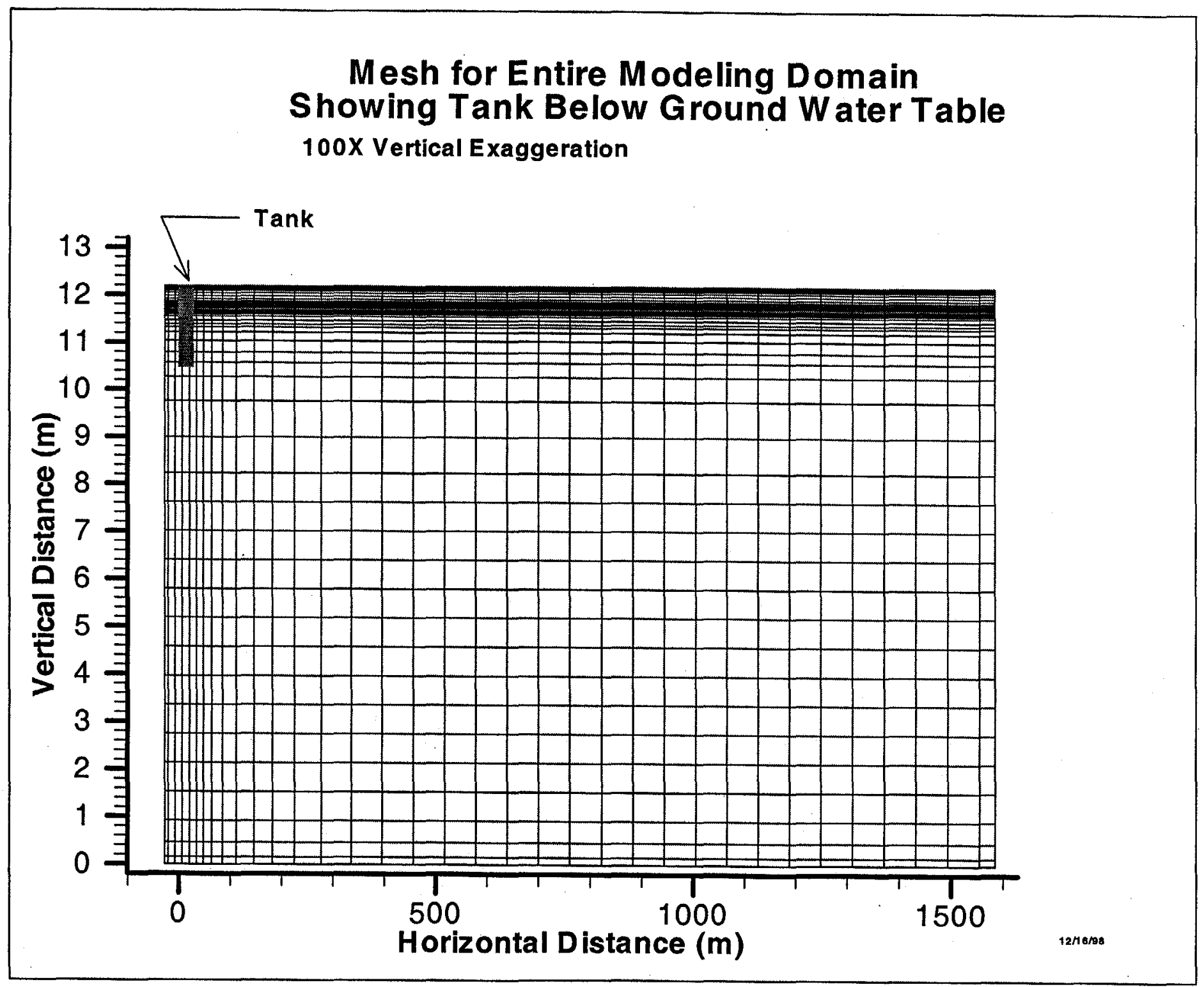

Figure 1. Total Mesh 


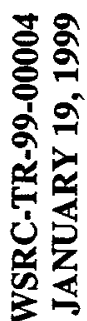

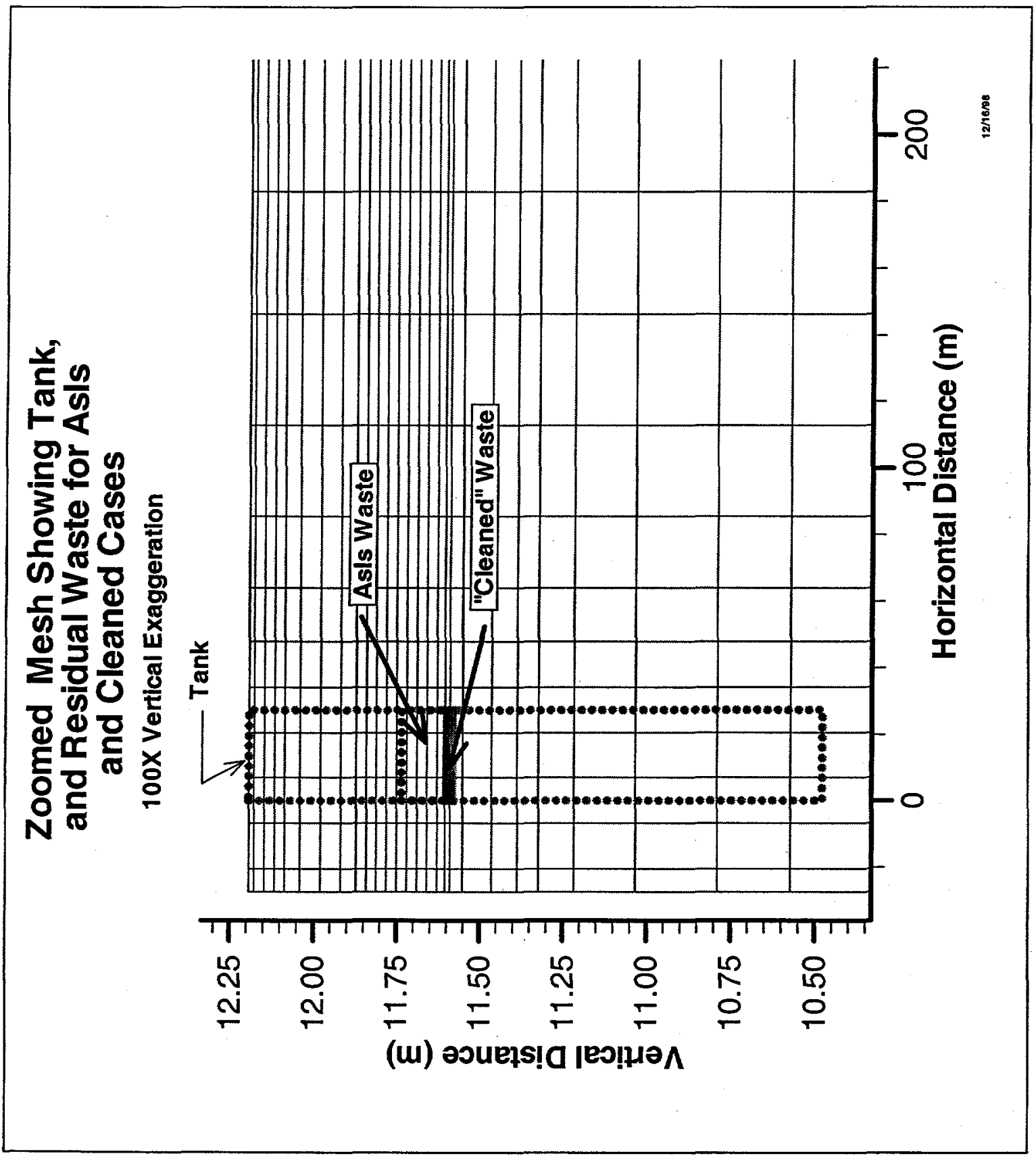


transient manner for the first 1,000 years using the intact steady-state saturations and fluxes. Beyond 1,000 years, the failed steady-state saturations and fluxes were used for the transport models.

\section{POST-MODELING ANALYSIS}

The numerical models produce intermediate results. Post-modeling analysis considers tank inventories and flow splitting. The numerical models used unit inventories as inputs to generate fractional concentrations and fluxes as outputs. The outputs must be multiplied by tank inventories to generate absolute results. Post-modeling analysis for tank inventories is discussed in Section 6.1.

The conceptual model was based on a simplified single aquifer system, rather than the complex threedimensional three-aquifer system that actually exists. Post-modeling analysis considers the flow split among the three aquifers and the dilution created by contaminants moving completely through one aquifer before reaching the next aquifer. Post-modeling analysis for flow splits is discussed in Section 6.2.

\subsection{Tank Inventories}

Tank inventories were calculated by multiplying the characterization concentration by the estimated tank residual waste mass. Tc-99 concentrations were measured (Hay, 1999) for four different samples. Those results are shown in Table 1. Based on annulus investigations using cameras, the remaining waste was estimated by $H L W$ to be about 22,000 pounds or $9979 \mathrm{~kg}$. The product of the measured concentrations and the estimated tank mass is the tank inventory - see Table 1. HLW selected the highest concentration of $0.40 \mu \mathrm{Ci} / \mathrm{g}$ to apply to the model.

\begin{tabular}{|l|c|c|c|}
\hline \multicolumn{3}{|c|}{ Table 1. Tc-99 Inventory Data from Tank 16 Samples } \\
& $\begin{array}{c}\text { Interior } \\
\text { HTF-086 }\end{array}$ & $\begin{array}{c}\text { Annulus } \\
\text { HTF-087 }\end{array}$ & $\begin{array}{c}\text { Composite } \\
\text { CPHTF-088 }\end{array}$ \\
\hline Conc. $(\mu \mathrm{Ci} / \mathrm{g})^{1}$ & 0.0620 & 0.13 & $<0.40$ \\
\hline Waste Inventory $(\mathrm{Ci})$ & 0.6190 & 1.30 & $<3.99$ \\
\hline
\end{tabular}

\subsection{Flow-Split Parameters}

Two flow-split parameters were developed. The first parameter considers the water flow that each aquifer carries to a seepline. The second parameter considers the dilution that occurs as contaminants migrate across one aquifer to reach a second aquifer.

Three aquifers that significantly affect the flow from Tank 16 to the seepline are as follows:

1) the uppermost aquifer referred to as the water table aquifer

2) the underlying aquifer referred to as the Barnwell-McBean aquifer

3) the lowest aquifer referred to as the Gordon or Congaree aquifer.

The simplified Tank 16 analysis only considers one composite aquifer. To accommodate the effect of each aquifer carrying a portion of the flow to different seepline locations, the first post-model splitting factor was developed. The Tank 20 analysis and a special analysis based on the three-dimensional aquifer model from the Composite Analysis (WSRC, 1997) were used to calculate the flow split. The three-dimensional Composite Analysis model was modified so that the only contaminant input was a unit concentration of Tc99 released at the Tank 16 location. The contaminant fluxes from the special Composite Analysis model that cross each aquifer are shown in Figure 3.

\footnotetext{
${ }^{1}$ Hay, 1998.
} 


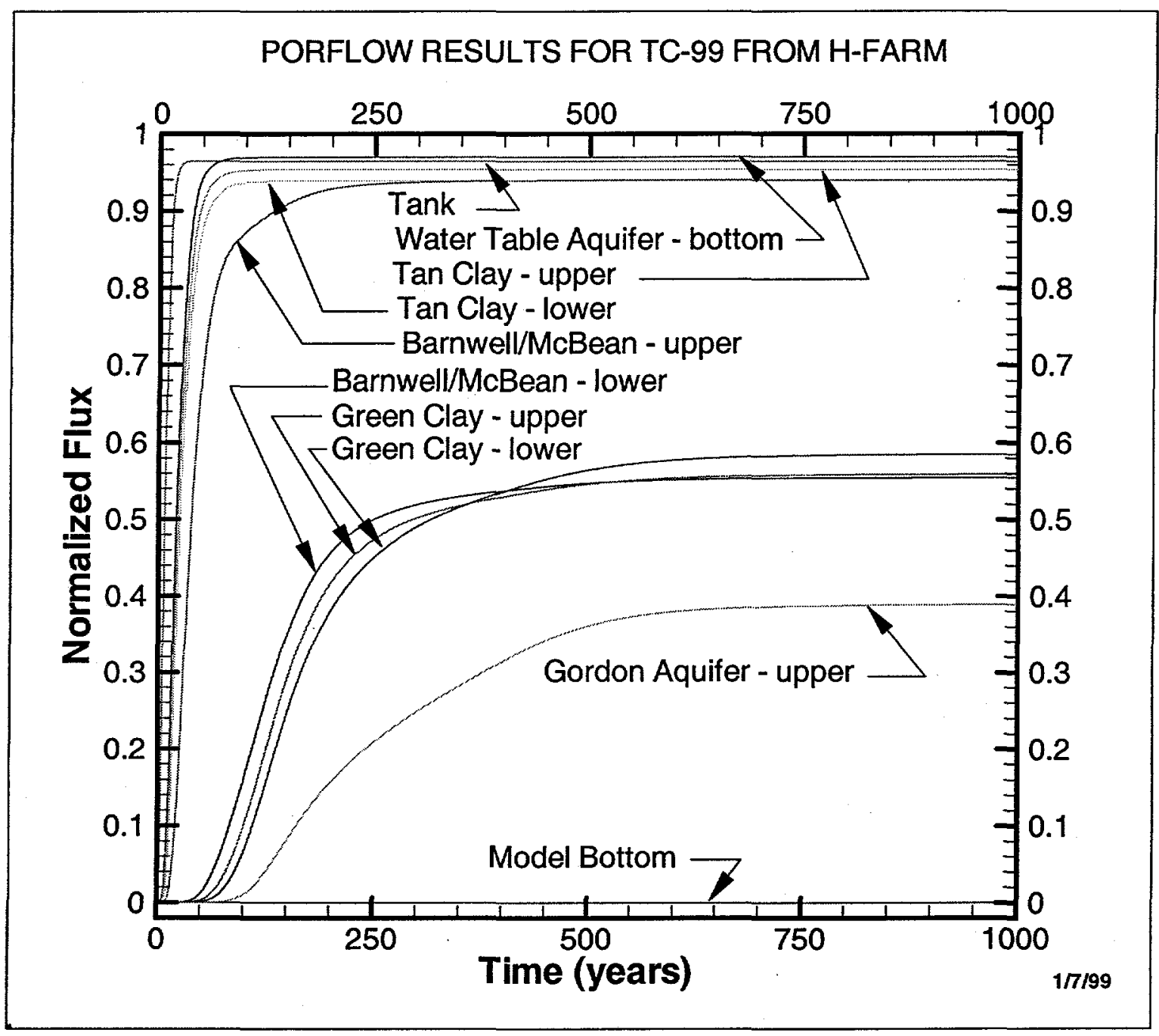

Figure 3. Flow Splits Between Aquifers 
The contaminant flux reaching a seepline from each aquifer was derived from the special Composite Analysis model and the Tank 20 analysis. The contaminant fluxes are presented in Table 2.

\begin{tabular}{l}
\hline Table 2. Contaminant Flux from an Aquifer to a Seepline (\%) \\
\begin{tabular}{|l|c|c|}
\hline Aquifer & Composite Analysis & Tank 20 Analysis \\
\hline Water table & 3 & 31 \\
\hline Barnwell-McBean & 57 & 65 \\
\hline Gordon & 40 & 4 \\
\hline
\end{tabular}
\end{tabular}

For the purposes of this study, an aquifer flow-splitting factor of $60 \%$ was applied to represent an average value for the Barnwell-McBean aquifer that carries most of the contaminant flux to a seepline.

A second flow-split factor was developed to address dilution that occurs as contaminants travel across the water table aquifer to reach the Barnwell-McBean aquifer. This effect was not explicitly modeled in the simplified two-dimensional analysis.

The dilution factor is expressed in terms of the extra depth of water that mixes with contaminants as they traverse the overlying aquifer. The dilution factor was defined as the thickness of the model divided by a composite thickness consisting of the model thickness and one-half the average thickness of the water table aquifer. Some contaminants will travel the entire thickness of the water table aquifer, while others will follow paths through thinner sections of the water table aquifer; thus only one-half the thickness of the water table aquifer was used for the composite thickness.

\section{MODEL RESULTS}

Each of the four numerical models was executed using PORFLOW. The two flow models represent the following conditions:

- The intact tank for the first 1,000 years

- The failed tank for all succeeding years.

The two transport models represent the following conditions:

- Residual waste without any removal

- Residual waste assuming that ninety percent of the waste is removed

Results for all models are presented in sections 7.1 through 7.4.

\subsection{Intact Tank Flow Model}

A flow model provides flux and saturation information for subsequent transport analyses. The flux discussed in this report is the volumetric flux (volume per unit time). The volumetric flux is equivalent to the Darcy velocity (length per unit time) multiplied by the cross-sectional area (length ${ }^{2}$. The Darcy velocities are plotted in the figures discussed below. The waste tank is shown in the figures to help understand its effects. Typically, the vertical exaggeration is 100 times normal.

Figure 4 depicts the flow directions for the intact tank model. These arrows show the direction of flow, but not the magnitude. The boundary conditions dictate that the flow at the top and base of the model domain must be parallel to those surfaces. Meanwhile, the boundary conditions require that the flow at the left- and right-hand sides of the model must be horizontal from left to right. The figure reflects the effects of the boundary conditions. All flow is left to right, except in the column centered about the tank. From the left- 


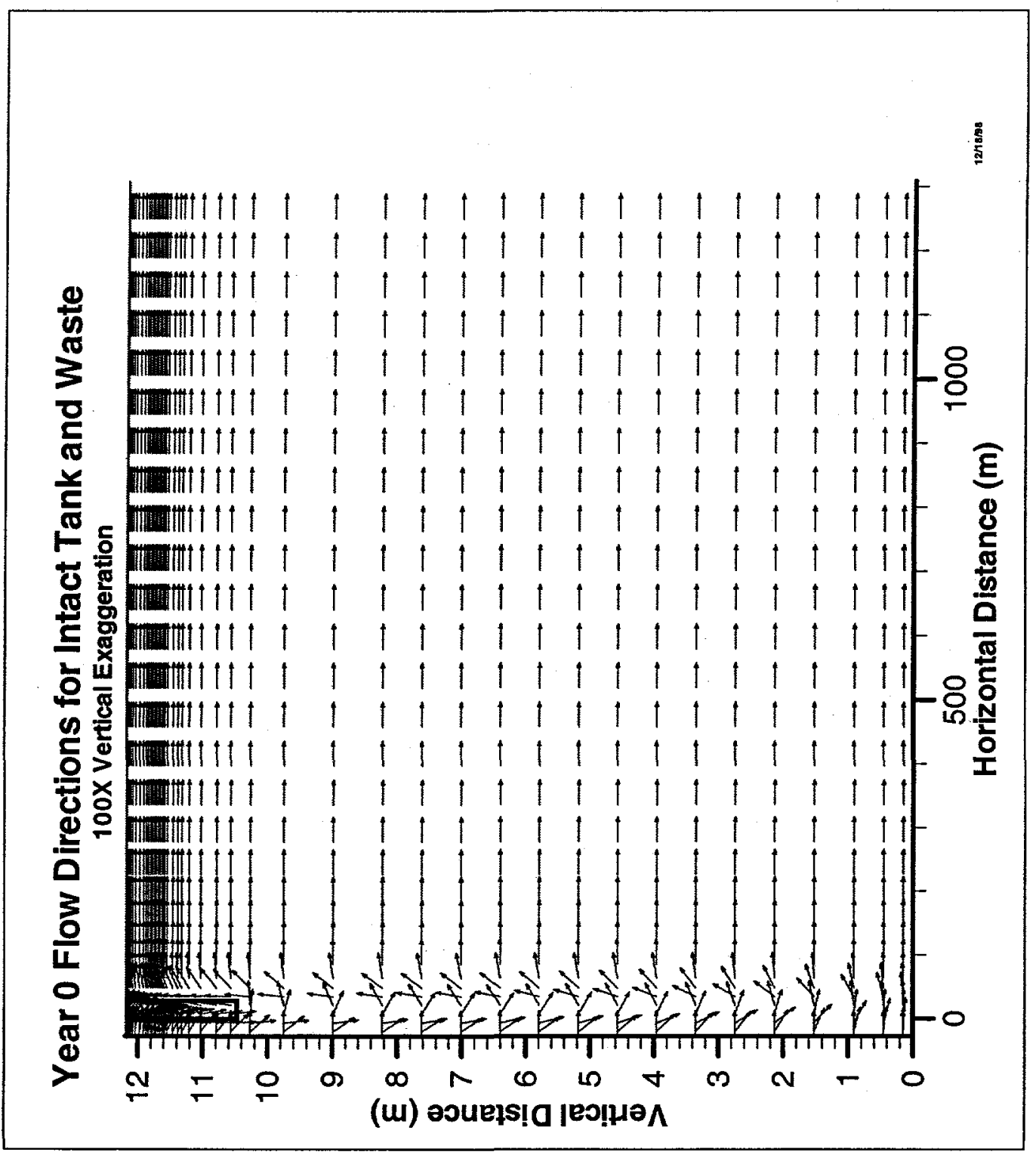


hand side, the flow drives down under the tank. On the right-hand side of the tank, the flow drives back up, then quickly adjusts to a horizontal flow state.

Figure 5 depicts the velocity vectors for the intact tank, so both magnitudes and directions are shown. The magnitudes of the vectors through the tank are very small compared to the vectors outside the tank. The magnitudes of the vectors adjacent to the column below the tank are much greater than all other vectors in the model domain. However, the magnitudes of the vectors directly below the tank are about the same as those for the unperturbed portion of the model domain. Without the large vertical exaggeration, the velocity vectors through the tank would appear much smaller and much closer to being horizontal.

\subsection{Failed Tank Flow Model}

Figure 6 depicts the flow directions for the failed tank. The boundary conditions are identical to those for the intact tank, and the figure reflects those conditions. In the column centered about the tank, from the left-hand side, the flow is up through the tank. On the right-hand side of the tank, the flow drives back down, then quickly adjusts to a horizontal flow state. The hydraulic conductivities for the tank are slightly different than the surrounding material. Additionally, the porosity and the bulk density have remained the same - an average of the intact and failed material. These differences are manifested as slight perturbations in the horizontal flow regime.

Figure 7 depicts the velocity vectors for the failed tank. The magnitudes of the vectors through the tank are slightly larger than the vectors outside the tank, because of the slight property differences. The effects diminish significantly with depth.

Figure 8 depicts the velocity vectors through a small portion of the model domain surrounding the failed tank. The tank is outlined by a series of dashes and dots. The waste region for the "As-Is" case is outlined along the top and sides by a solid line. The bottom portion of that waste region is identical to the waste region for the "Cleaned" case that is outlined by a series of dots.

\subsection{As-Is Waste Transport Model}

The Tc-99 fractional flux entering the seepline is shown in Figure 9. In Figure 9 and other figures, years represent the increment of time from the present, not the actual or Gregorian year. The fractional flux is the amount of curies per unit curie of inventory that crosses the boundary of the model domain at the simulated seepline. The curve rises very sharply until about 1,000 years. At 1,000 years the flow regime is changed because of the tank failure, resulting in a short-term lateral shift in the flux followed by a return to a sharply rising curve.

Near 2,000 years the flux reaches its peak and flattens for the duration of the analysis period. The peak of $4.78 \mathrm{E}-5 \mathrm{Ci} / \mathrm{Ci}$ is attained in 5175 .

The concentration profile at the peak is shown in Figure 10. The highest concentrations throughout the model domain are found at the waste. The concentration contours extend from left to right with a slight upward curve near the end. For the lower contours, the base slopes slightly downward with an abrupt upturn at the far right edge of the model domain. The concentration levels fall rapidly with depth - a decrease of three orders of magnitude over five or six meters. 


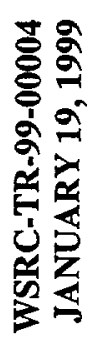

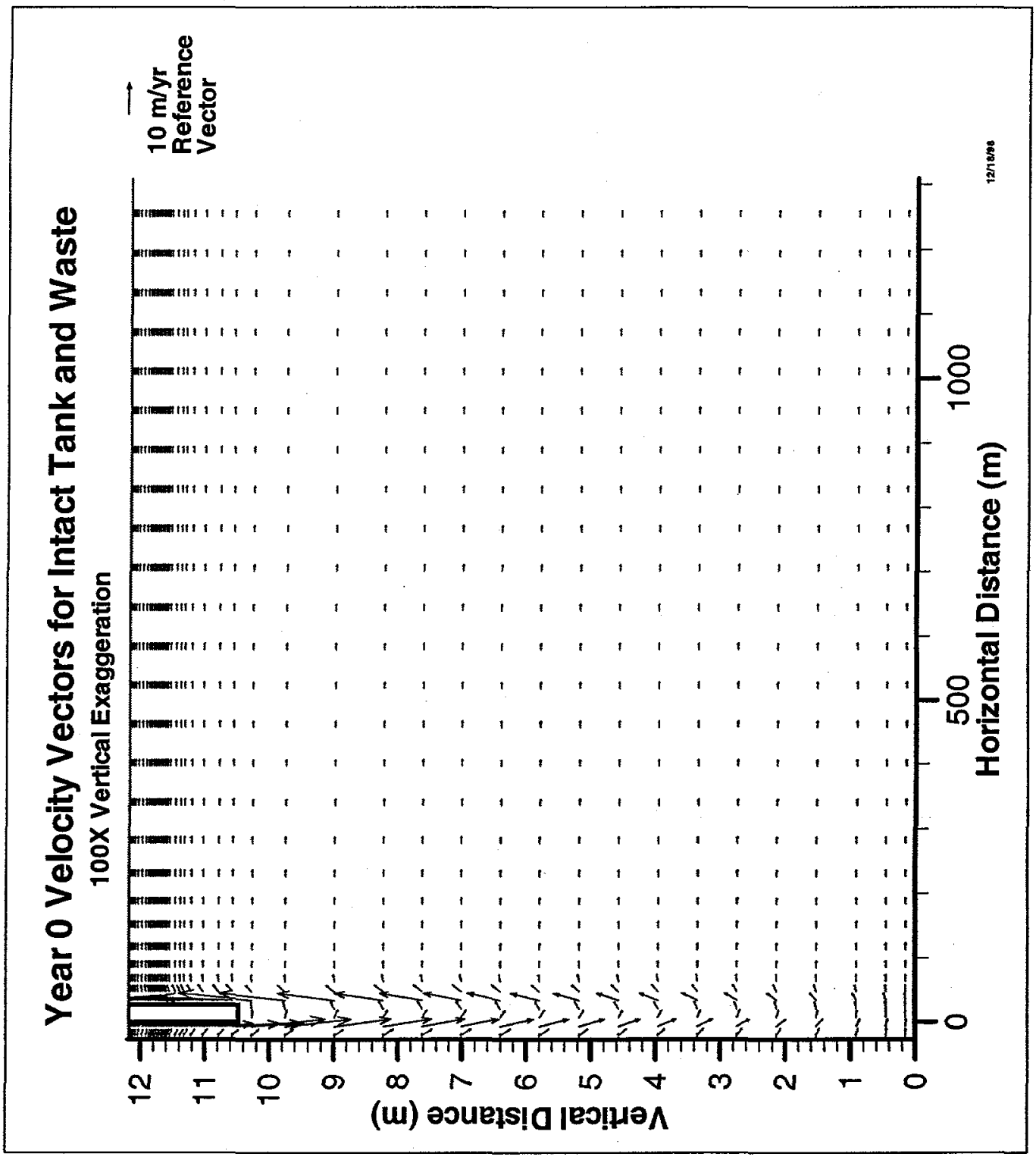




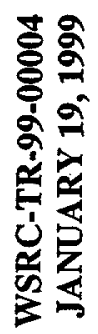

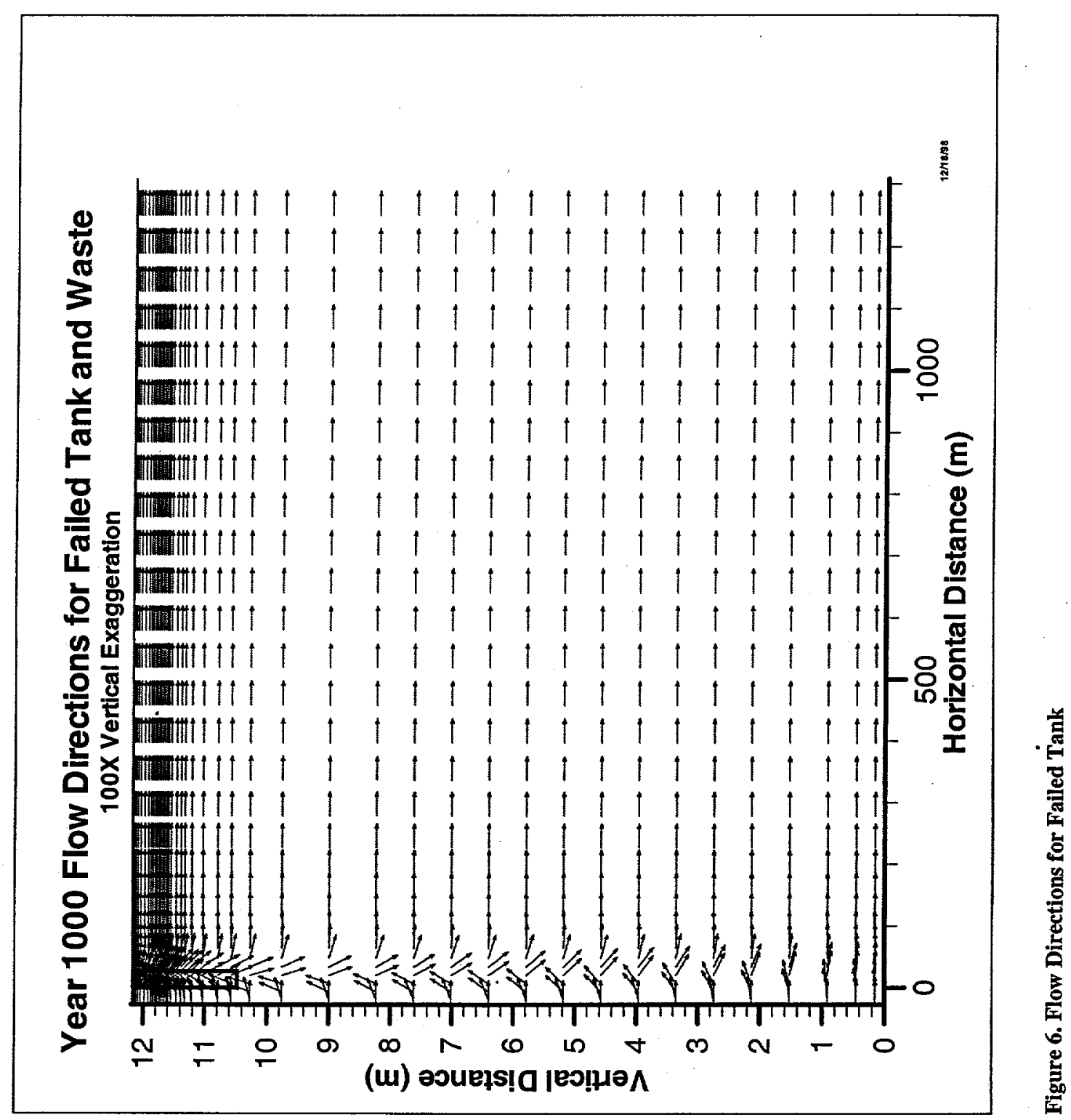




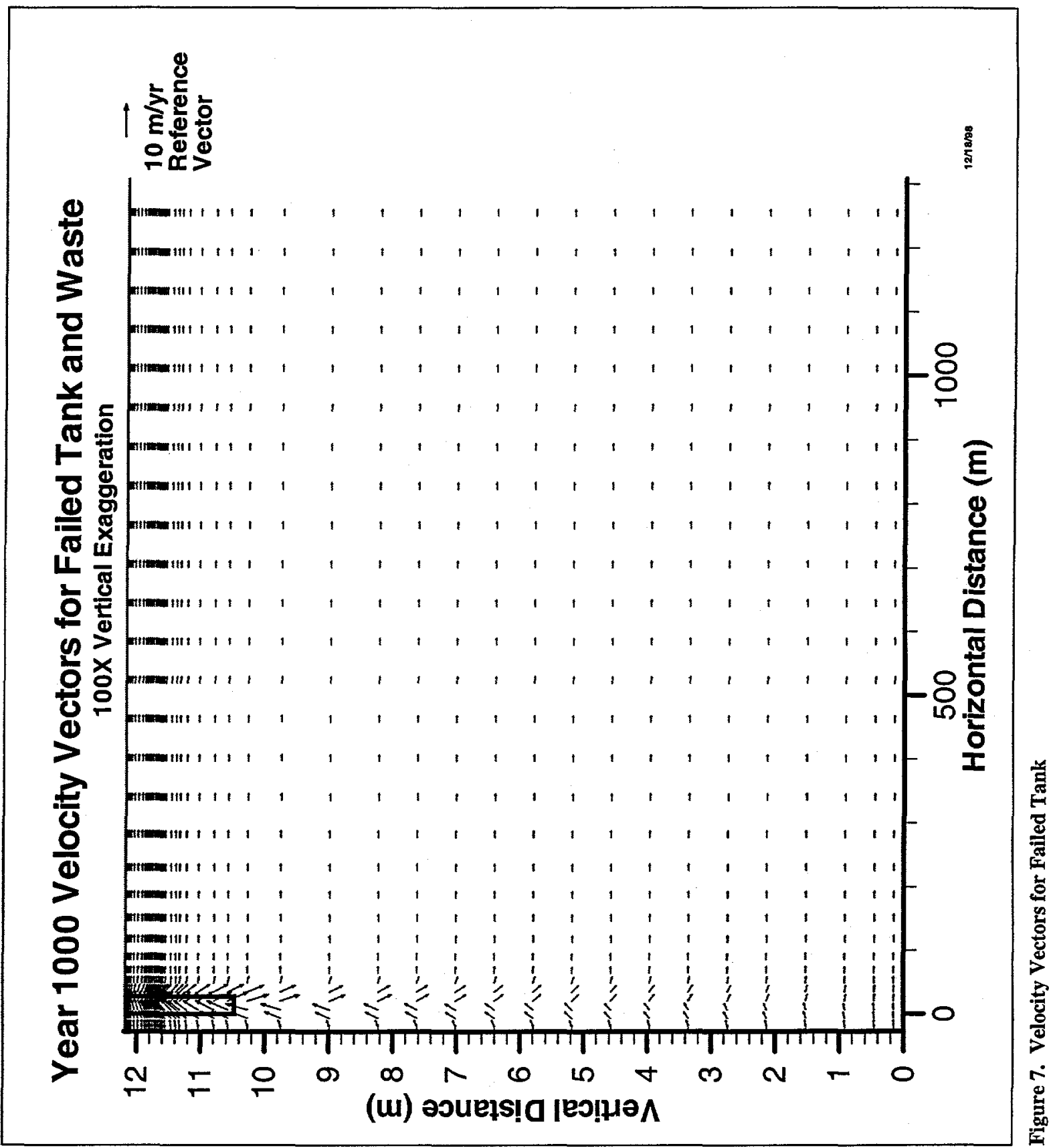




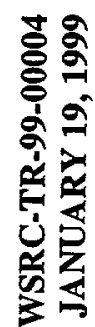

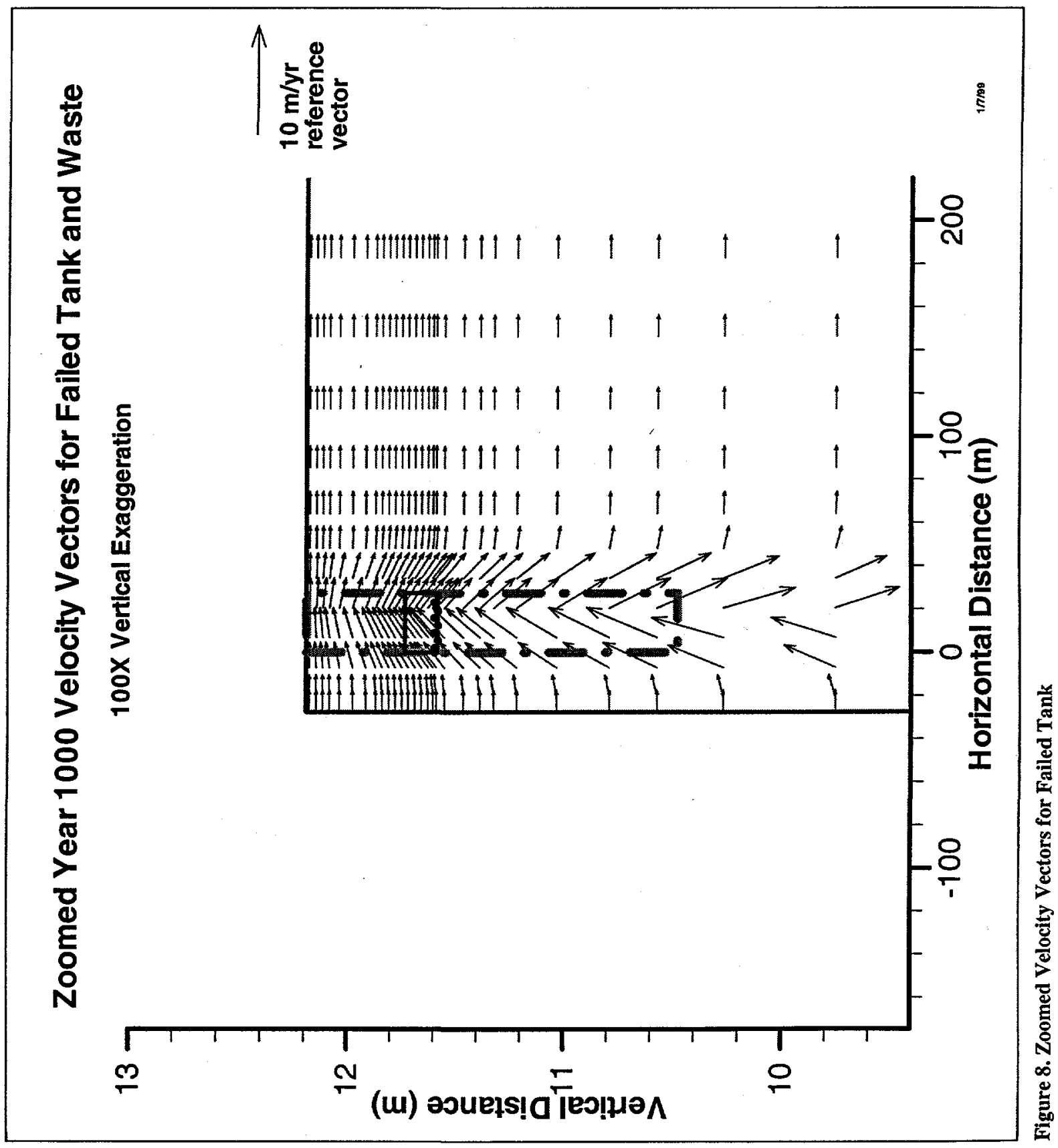




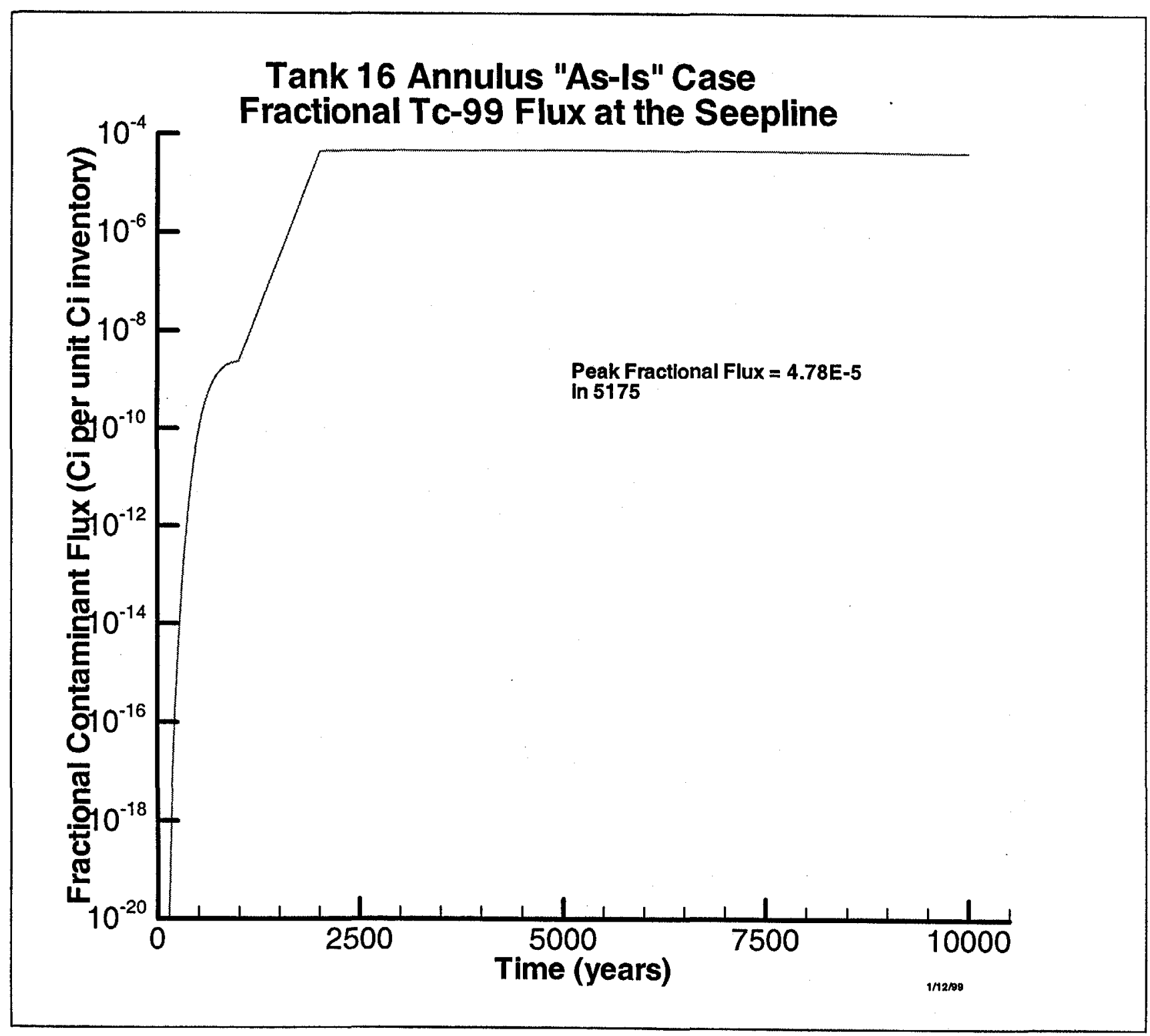

Figure 9 Fractional Tc-99 Flux at the Seepline for "As-Is" Case 


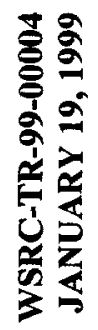

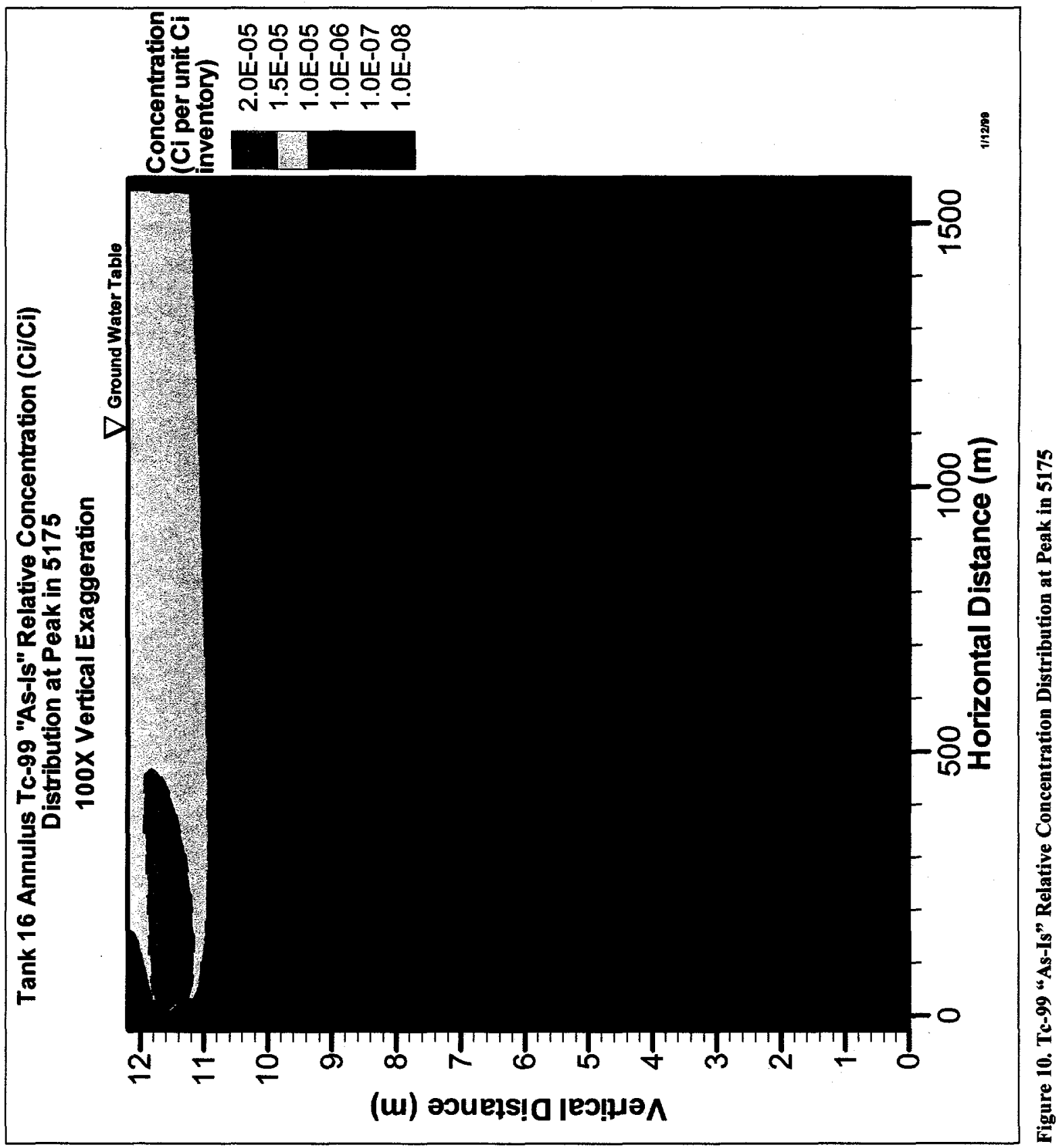




\subsection{Cleaned Waste Transport Model}

Figure 11 shows the Tc-99 fractional flux entering the seepline. The "Cleaned" case curve is very similar to the "As-Is" case curve. The curve rises sharply until about 1,000 years. At 1,000 years the flow regime changes because of tank failure, resulting in a short-term lateral shift in the flux, then a sharply rising curve.

Near 2,000 years the flux reaches its peak and flattens for the duration of the analysis period. The peak of $5.29 \mathrm{E}-5 \mathrm{Ci} / \mathrm{Ci}$ is slightly higher than the $4.78 \mathrm{E}-5 \mathrm{Ci} / \mathrm{Ci}$ for the "As-Is" case. The peak is reached later than the peak for the "As-Is" case (6173 years vs. 5175 years).

The concentration profile at the peak is shown in Figure 12. The profile is very similar to that for the "AsIs" case. The most noticeable difference is that the highest contours near the source do not have as strong of an upward curve at the end, possibly caused by the thinner waste section. The highest concentrations throughout the model domain are found at the waste. The concentration contours extend from left to right with a slight upward curve near the end. For the lower contours, the base slopes slightly downward with an abrupt upturn at the far right edge of the model domain. The concentration levels fall rapidly with depth three orders of magnitude are lost over five or six meters.

\section{POST-MODELING RESULTS}

The modeling results are expressed in terms of fractional contaminant fluxes. In order to determine the peak doses at the seepline, several post-modeling operations are required.

The modeling results are divided by the model's annual water flow to the seepline to determine model concentrations. The model concentrations are adjusted for aquifer splitting and for the aquifer thickness versus the modeled thickness to determine actual concentration. Finally, concentrations are multiplied by a person's annual water intake and by the Tc-99 dose conversion factor. Dose results are shown in Table 3, while the worksheets for the adjustments are presented in Tables A.6 and A.7.

\begin{tabular}{|l|c|c|}
\hline \multicolumn{3}{|l|}{ Table 3. Peak Tc-99 Doses at Seepline } \\
\hline Description & Peak Dose (mrem/yr) & $\begin{array}{c}\text { Time } \\
\text { (years in future) }\end{array}$ \\
\hline As-Is Case & 2.90 & 5175 \\
\hline Cleaned Case & 0.32 & 6173 \\
\hline
\end{tabular}

For comparison, the Tank 20 (DOE, 1997) model results for Tc-99 were scaled to the inventory used in the Tank 16 model. The scaled Tank 20 peak dose would be about $0.94 \mathrm{mrem} / \mathrm{yr}$. Tank 20 sits above the water table, while the base of Tank 16 sits in the water table where the horizontal release of contaminants can dominate. The predicted Tank 20 peak occurs at 1855 years for the Barnwell-McBean aquifer. The Tank 16 results are very near their peak by 2000 years, so the times of the peaks are comparable.

\section{CONCLUSIONS}

Analysis results of peak doses at the seepline indicate that Tc-99 is about $2.9 \mathrm{mrem} / \mathrm{yr}$ at 5,175 years for the current annulus inventory (the "As-Is" case). That peak dose is slightly below the regulatory limit of 4 $\mathrm{mrem} / \mathrm{yr}$. If 90 percent of the waste is removed (the "Cleaned" case), the peak seepline dose would be reduced to $0.32 \mathrm{mrem} / \mathrm{yr}$ at 6,173 years. Removing 90 percent of the waste delays the peak for about 1,000 years, although each curve closely approaches its peak by 2,000 years.

These results are based on an estimate of 22,000 pounds of waste currently in the annulus and using the highest concentration for any of the waste samples that were analyzed in the laboratory. This analysis only examines Tc-99. Preliminary analyses indicated that Tc-99 was the major contributor to dose, hence this analysis focused only on Tc-99. 


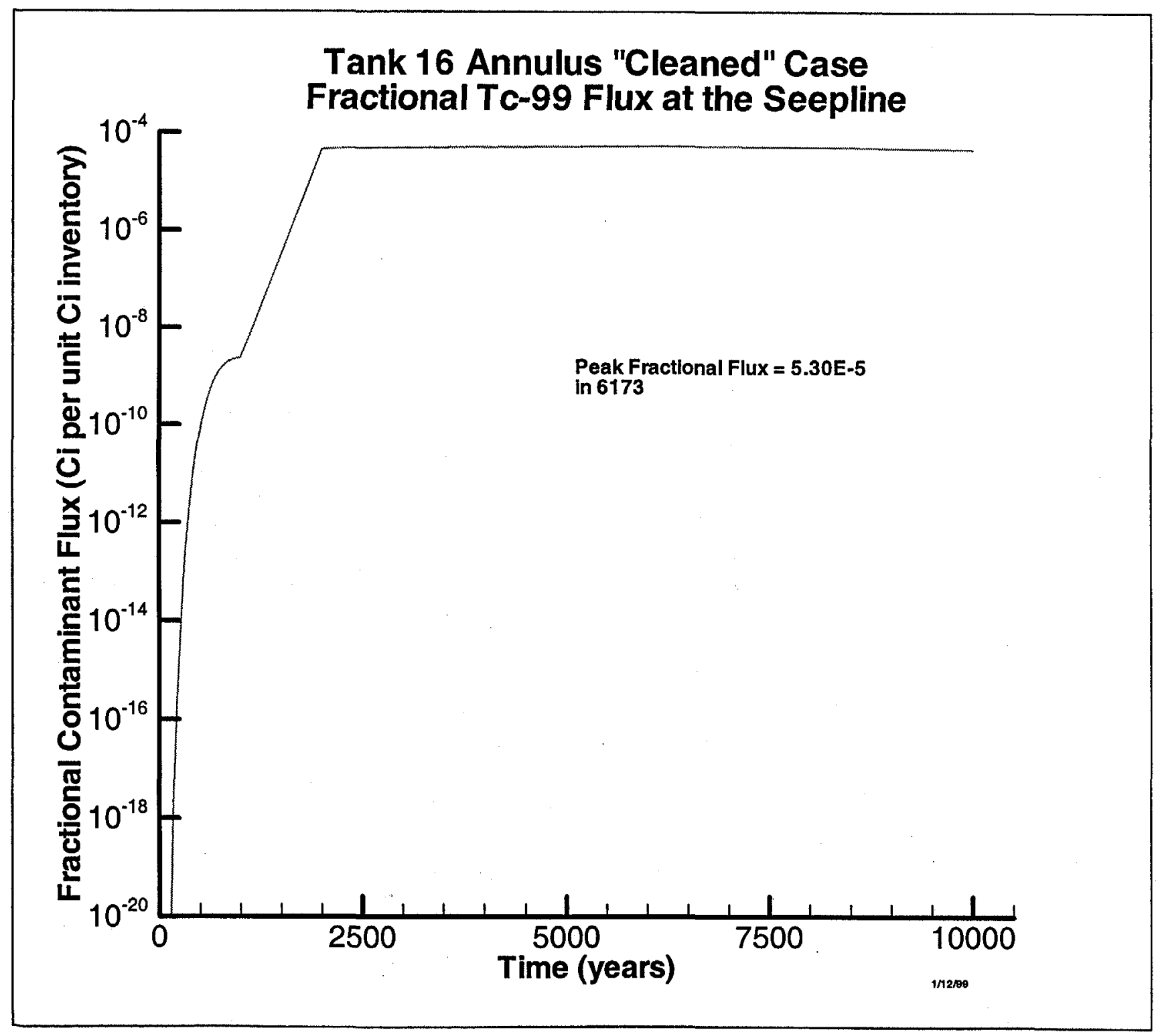

Figure 11. Fractional Tc-99 Flux at the Seepline for "Cleaned" Case 


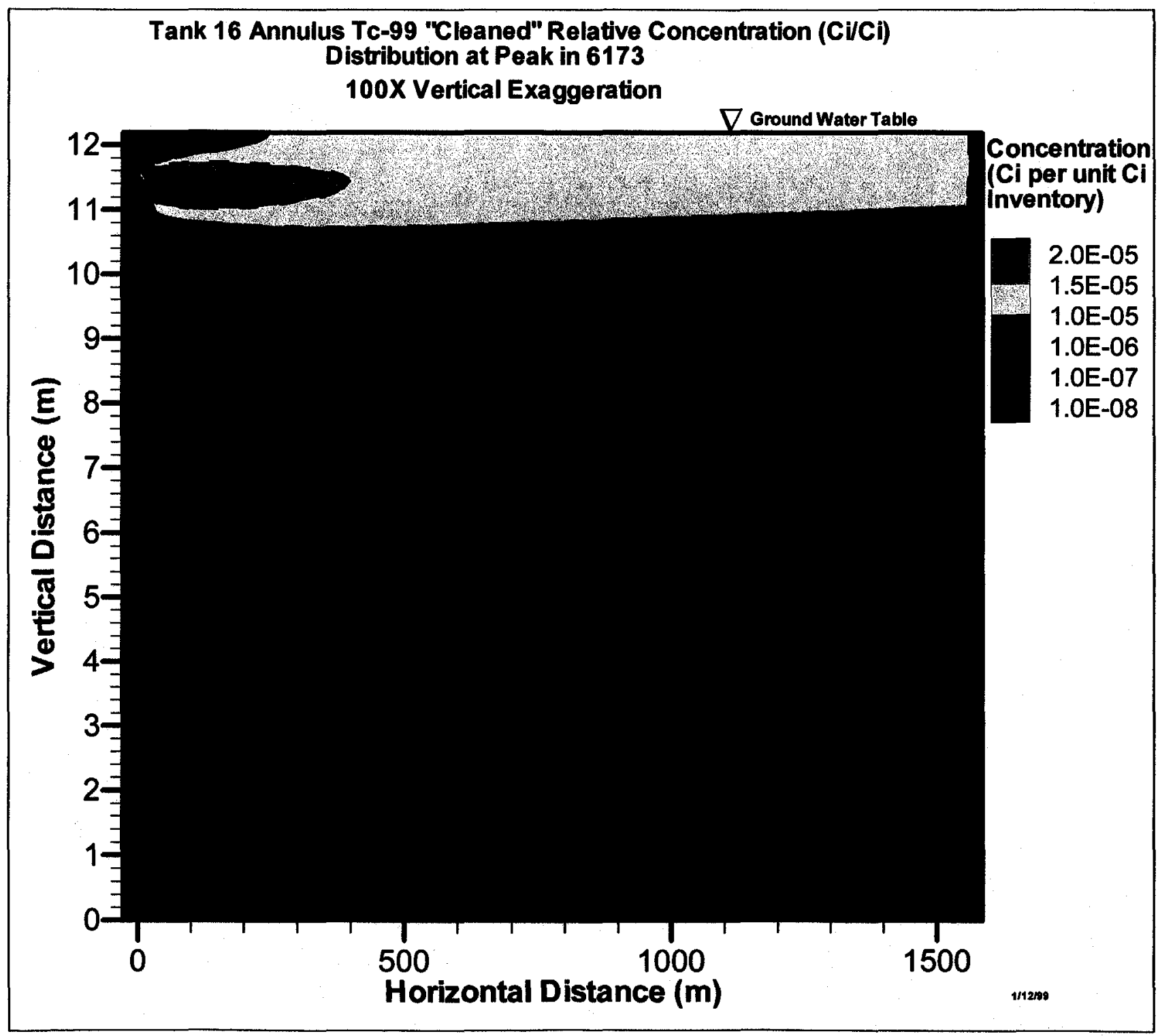

Figure 12. Tc-99 "Cleaned" Relative Concentration Distribution at Peak in 6173 


\section{REFERENCES}

Collard, 1998, PORFLOW Capabilities, Usage History, and Testing, WSRC-RP-98-00311, May 6.

DOE (U.S. Department of Energy), 1996, Industrial Wastewater Closure Plan for F- and H-Area HighLevel Waste Tank Systems, Savannah River Operations Office, Aiken, South Carolina, July 10, Rev. 1.

DOE (U.S. Department of Energy), 1997, Industrial Wastewater Closure Module for the High-Level Waste Tank 20 System, Savannah River Operations Office, Aiken, South Carolina, January 8, Rev. 1.

Freeze, R. A. and J. A. Cherry, 1979, Groundwater, Prentice-Hall, Inc., Englewood Cliffs, New Jersey.

ACRi, 1998, PORFLOW, a software tool for multiphase fluid flow, heat and mass transport in fractured porous media, USER'S MANUAL, VERSION 4.00, Analytical \& Computational Research, Inc., 1931 Stradella Road, Bel Air, California.

Hay, 1999, Results of the Characterization and Dissolution Tests of Samples from Tank 16H, WSRC-RP. 99-00124, January 18. 


\section{APPENDIX A}

\section{Table A-1. Decay Rates}

Radionuclide

Tc-99 Half-Life (years)

2.13E5

\section{Table A-2. Infiltration}

(Tank $20^{2}$ value at top of each table cell. Tank16 value at bottom of each table cell.)

\begin{tabular}{|c|c|}
\hline Time (years) & Rate $(\mathrm{cm} / \mathrm{yr})$ \\
\hline $0-1,000$ (intact) & 4 \\
& NA \\
\hline $1,001-10,000$ (failed) & 40 \\
& NA \\
\hline
\end{tabular}

2 DOE, 1997, Table A-10, page A-23. 
Table A-3. Unsaturated Zone Information

(Tank20 $0^{3}$ value at top of each table cell. Tank16 value at bottom of each table cell.)

\begin{tabular}{|c|c|c|c|c|c|c|c|c|c|}
\hline Description & $\begin{array}{l}\text { Concrete Bas } \\
\text { Intact } \\
0-1000 \mathrm{yr}\end{array}$ & $\begin{array}{r}\text { Failed } \\
>1000 \mathrm{yr}\end{array}$ & Intact & Failed & $\begin{array}{l}\text { Vadose } \\
\text { Zone }\end{array}$ & $\begin{array}{l}\text { Water } \\
\text { Table } \\
\text { Aquifer }\end{array}$ & $\begin{array}{l}\text { Tan Clay } \\
\text { Layer }\end{array}$ & $\begin{array}{l}\text { Barnwell- } \\
\text { McBean } \\
\text { Aquifer }\end{array}$ & $\begin{array}{l}\text { Green } \\
\text { Clay } \\
\text { Layer }\end{array}$ \\
\hline Thickness (ft) & $\begin{array}{r}0.58 \\
0.58 \\
\end{array}$ & $\begin{array}{r}0.58 \\
0.58 \\
\end{array}$ & $\begin{array}{r}\text { NA } \\
0.50 \\
\end{array}$ & $\begin{array}{r}\text { NA } \\
0.50 \\
\end{array}$ & $\begin{array}{l}5.4 \\
0.0 \\
\end{array}$ & $\begin{array}{r}40.0 \\
40.0^{4} \\
\end{array}$ & $\begin{array}{r}3.0 \\
\mathrm{NA} \\
\end{array}$ & $\begin{array}{r}60.0 \\
\mathrm{NA} \\
\end{array}$ & $\begin{array}{r}5.0 \\
\text { NA } \\
\end{array}$ \\
\hline Dry Bulk Density $(\mathrm{g} / \mathrm{cc})^{5}$ & $\begin{array}{l}2.21 \\
1.96 \\
\end{array}$ & $\begin{array}{l}1.64 \\
1.96 \\
\end{array}$ & $\begin{array}{r}\text { NA } \\
1.96 \\
\end{array}$ & $\begin{array}{r}\mathrm{NA} \\
1.96 \\
\end{array}$ & $\begin{array}{r}1.59 \\
\text { NA } \\
\end{array}$ & $\begin{array}{l}1.59 \\
1.59 \\
\end{array}$ & $\begin{array}{r}1.36 \\
\text { NA } \\
\end{array}$ & $\begin{array}{r}1.59 \\
\text { NA }\end{array}$ & $\begin{array}{r}1.39 \\
\text { NA }\end{array}$ \\
\hline Longitudinal Dispersion (ft) & $\begin{array}{r}0.0058 \\
\text { NA } \\
\end{array}$ & $\begin{array}{r}0.0058 \\
\text { NA } \\
\end{array}$ & $\begin{array}{l}\text { NA } \\
\text { NA } \\
\end{array}$ & $\begin{array}{l}\text { NA } \\
\text { NA } \\
\end{array}$ & $\begin{array}{r}0.054 \\
\mathrm{NA} \\
\end{array}$ & $\begin{array}{r}0.40 \\
\mathrm{NA} \\
\end{array}$ & $\begin{array}{r}0.03 \\
\text { NA } \\
\end{array}$ & $\begin{array}{r}0.60 \\
\text { NA } \\
\end{array}$ & $\begin{array}{r}0.050 \\
\text { NA } \\
\end{array}$ \\
\hline $\begin{array}{l}\text { Vertical Hydraulic } \\
\text { Conductivity }(\mathrm{cm} / \mathrm{s})\end{array}$ & $\begin{array}{l}9.6 \mathrm{E}-9 \\
9.6 \mathrm{E}-9 \\
\end{array}$ & $\begin{array}{l}6.6 \mathrm{E}-3 \\
6.6 \mathrm{E}-3 \\
\end{array}$ & $\begin{array}{r}\mathrm{NA} \\
9.6 \mathrm{E}-9 \\
\end{array}$ & $\begin{array}{r}\mathrm{NA} \\
6.6 \mathrm{E}-3 \\
\end{array}$ & $\begin{array}{r}7.1 \mathrm{E}-3 \\
\mathrm{NA} \\
\end{array}$ & $\begin{array}{r}7.1 \mathrm{E}-3 \\
3.8 \mathrm{E}-3^{6} \\
\end{array}$ & $\begin{array}{r}1.6 \mathrm{E}-6 \\
\mathrm{NA} \\
\end{array}$ & $\begin{array}{r}5.6 \mathrm{E}-4 \\
\mathrm{NA} \\
\end{array}$ & $\begin{array}{r}4.4 \mathrm{E}-9 \\
\mathrm{NA} \\
\end{array}$ \\
\hline $\begin{array}{l}\text { Horizontal Hydraulic } \\
\text { Conductivity }(\mathrm{cm} / \mathrm{s})^{7}\end{array}$ & $\begin{array}{r}\mathrm{NA} \\
3.8 \mathrm{E}-8 \\
\end{array}$ & $\begin{array}{r}\mathrm{NA} \\
2.6 \mathrm{E}-2 \\
\end{array}$ & $\begin{array}{r}\mathrm{NA} \\
3.8 \mathrm{E}-8 \\
\end{array}$ & $\begin{array}{r}\mathrm{NA} \\
2.6 \mathrm{E}-2 \\
\end{array}$ & $\begin{array}{l}\text { NA } \\
\text { NA } \\
\end{array}$ & $\begin{array}{r}\mathrm{NA} \\
1.5 \mathrm{E}-2 \\
\end{array}$ & $\begin{array}{l}\text { NA } \\
\text { NA }\end{array}$ & $\begin{array}{l}\text { NA } \\
\text { NA }\end{array}$ & $\begin{array}{l}\text { NA } \\
\text { NA }\end{array}$ \\
\hline Total Porosity & $\begin{array}{r}0.15 \\
0.26^{8} \\
\end{array}$ & $\begin{array}{r}0.38 \\
0.26^{8} \\
\end{array}$ & $\begin{array}{r}\text { NA } \\
0.26^{8} \\
\end{array}$ & $\begin{array}{r}\mathrm{NA} \\
0.26^{8} \\
\end{array}$ & $\begin{array}{r}0.35 \\
\text { NA } \\
\end{array}$ & $\begin{array}{l}0.35 \\
0.35 \\
\end{array}$ & $\begin{array}{r}0.40 \\
\text { NA } \\
\end{array}$ & $\begin{array}{r}0.35 \\
\text { NA }\end{array}$ & $\begin{array}{r}0.40 \\
\mathrm{NA}\end{array}$ \\
\hline Effective Porosity $^{8}$ & $\begin{array}{r}\mathrm{NU} \\
0.26 \\
\end{array}$ & $\begin{array}{l}\mathrm{NU} \\
0.26 \\
\end{array}$ & $\begin{array}{r}\mathrm{NU} \\
\mathbf{0 . 2 6} \\
\end{array}$ & $\begin{array}{r}\mathrm{NU} \\
0.26 \\
\end{array}$ & $\begin{array}{l}\mathrm{NU} \\
\mathrm{NA} \\
\end{array}$ & $\begin{array}{r}\mathrm{NU} \\
0.20 \\
\end{array}$ & $\begin{array}{l}\text { NU } \\
\text { NA } \\
\end{array}$ & $\begin{array}{l}\mathrm{NU} \\
\mathrm{NA}\end{array}$ & $\begin{array}{l}\text { NU } \\
\text { NA }\end{array}$ \\
\hline Field Capacity & $\begin{array}{r}0.15 \\
\text { NA } \\
\end{array}$ & $\begin{array}{r}0.09 \\
\text { NA } \\
\end{array}$ & $\begin{array}{l}\text { NU } \\
\text { NA } \\
\end{array}$ & $\begin{array}{l}\text { NU } \\
\text { NA }\end{array}$ & $\begin{array}{r}0.12 \\
\mathrm{NA} \\
\end{array}$ & $\begin{array}{r}0.35 \\
\text { NA } \\
\end{array}$ & $\begin{array}{r}0.334 \\
\text { NA } \\
\end{array}$ & $\begin{array}{r}0.35 \\
\text { NA } \\
\end{array}$ & $\begin{array}{r}0.325 \\
\text { NA } \\
\end{array}$ \\
\hline Matrix Compress. $(1 / \mathrm{Pa})^{9}$ & $\begin{array}{r}\text { NR } \\
1 . E-9 \\
\end{array}$ & $\begin{array}{r}\text { NR } \\
1 . \mathrm{E}-8 \\
\end{array}$ & $\begin{array}{r}\text { NR } \\
\text { 1.E-9 } \\
\end{array}$ & $\begin{array}{r}\text { NR } \\
\text { 1.E-8 } \\
\end{array}$ & $\begin{array}{l}\text { NR } \\
\text { NA } \\
\end{array}$ & $\begin{array}{r}\mathrm{NR} \\
1 . \mathrm{E}-8 \\
\end{array}$ & $\begin{array}{l}\text { NR } \\
\text { NA }\end{array}$ & $\begin{array}{l}\text { NR } \\
\text { NA } \\
\end{array}$ & $\begin{array}{l}\mathrm{NR} \\
\mathrm{NA} \\
\end{array}$ \\
\hline
\end{tabular}

${ }^{3}$ DOE, 1997, Table A-7, page A-22. NA: not applicable, NU: not used, NR: not reported. Van Genuchten alpha and " $n$ " not used and not applicable.

${ }^{4}$ Tank and surrounding soil extend two feet above inside base of tank to the water table

${ }^{5}$ Assuming particle density of 2.65 , use bulk density $=$ particle density * $(1-$ porosity $)$.

${ }^{6}$ Average from Water Table aquifer and Barnwell-McBean aquifer

${ }^{7}$ Anisotropy ratio of 4 assumed for Tank16 annulus model

${ }^{8}$ Tank16 annulus model concrete and waste set to average of Tank20 models for intact and failed states.

${ }^{9}$ Freeze and Cherry, 1979, page 55. For concrete and waste, assumed high value sound rock. For others assumed mid-range value for sand. 


\begin{tabular}{|c|c|c|c|}
\hline Description & $\begin{array}{l}\text { Water Table Aquifer } \\
\text { (FMB) }\end{array}$ & $\begin{array}{l}\text { Barnwell-McBean } \\
\text { Aquifer (FMB) }\end{array}$ & Congaree Aquifer (UTR) \\
\hline Thickness (ft) & $\begin{array}{r}40.0 \\
40.0\end{array}$ & $\begin{array}{r}60.0 \\
\text { NA }\end{array}$ & $\begin{array}{r}100.0 \\
\text { NA }\end{array}$ \\
\hline Length $(\mathrm{ft})$ & $\begin{array}{l}5,000 \text { to } 15,000^{11} \\
5374^{12}(1628 \mathrm{~m})\end{array}$ & $\begin{array}{l}\text { NR } \\
\text { NA }\end{array}$ & $\begin{array}{l}\text { NR } \\
\text { NA }\end{array}$ \\
\hline Dry Bulk Density (g/cc) & $\begin{array}{l}1.59 \\
1.59\end{array}$ & $\begin{array}{r}1.59 \\
\mathrm{NA}\end{array}$ & $\begin{array}{r}1.64 \\
\text { NA }\end{array}$ \\
\hline Longitudinal Dispersion (ft) & $\begin{array}{r}\text { NR }(0.40)^{13} \\
53(16.28 \mathrm{~m})\end{array}$ & $\begin{array}{r}\text { NR }(0.60)^{13} \\
\text { NA }\end{array}$ & $\begin{array}{l}\text { NR } \\
\text { NA }\end{array}$ \\
\hline $\begin{array}{l}\text { Vertical Hydraulic } \\
\text { Conductivity }(\mathrm{cm} / \mathrm{s})\end{array}$ & $\begin{array}{r}\text { NA }(7.1 \mathrm{E}-3)^{13} \\
3.8 \mathrm{E}-3^{14}\end{array}$ & $\begin{array}{r}\mathrm{NA}(5.6 \mathrm{E}-4)^{13} \\
\text { NA }\end{array}$ & $\begin{array}{l}\text { NA } \\
\text { NA }\end{array}$ \\
\hline $\begin{array}{l}\text { Horizontal Hydraulic } \\
\text { Conductivity }(\mathrm{cm} / \mathrm{s})^{15}\end{array}$ & $\begin{array}{r}\mathrm{NR} \\
1.5 \mathrm{E}-2\end{array}$ & $\begin{array}{l}\text { NR } \\
\text { NA }\end{array}$ & $\begin{array}{l}\text { NR } \\
\text { NA }\end{array}$ \\
\hline Pore Velocity $(\mathrm{ft} /$ day $[\mathrm{m} / \mathrm{yr}])$ & $\begin{array}{r}0.12[13.35] \\
0.09[10.24]^{14} \\
\end{array}$ & $\begin{array}{r}0.064[7.13] \\
\mathrm{NA} \\
\end{array}$ & $\begin{array}{r}0.23[25.60] \\
\mathrm{NA} \\
\end{array}$ \\
\hline Total Porosity & $\begin{array}{r}0.35 \\
0.35^{11}\end{array}$ & $\begin{array}{r}0.35 \\
\text { NA }\end{array}$ & $\begin{array}{r}0.34 \\
\text { NA }\end{array}$ \\
\hline Effective Porosity & $\begin{array}{r}0.20 \\
0.20^{11} \\
\end{array}$ & $\begin{array}{r}0.20 \\
\mathrm{NA}\end{array}$ & $\begin{array}{r}0.25 \\
\text { NA }\end{array}$ \\
\hline Matrix Compressibility (1/Pa) & $1 \mathrm{E}-8^{16}$ & $1 \mathrm{E}-8^{16}$ & $1 \mathrm{E}-8^{15}$ \\
\hline
\end{tabular}

\section{Table A-5. Distribution Coefficients, $\mathbf{K}_{\mathrm{d}}(\mathrm{ml} / \mathrm{g})$}

(Tank2017 value at top of each table cell. Tank16 value at bottom of each table cell.)

\begin{tabular}{|c|c|c|c|c|}
\hline Contaminant & Soil & $\begin{array}{l}\text { Reducing Contaminated } \\
\text { Zone }\end{array}$ & Reducing Concrete & Clay \\
\hline Tc-99 & $\begin{array}{l}0.36 \\
0.36\end{array}$ & $\begin{array}{r}1000.00 \\
1000.00\end{array}$ & $\begin{array}{l}1000.00 \\
1000.00\end{array}$ & $\begin{array}{r}1.00 \\
\text { NU }\end{array}$ \\
\hline
\end{tabular}

${ }^{10}$ DOE, 1997, Table A-8, page A-23. NA: not applicable, NR: not reported, NU: not used.

${ }^{11}$ DOE, 1996, page 3-16.

${ }^{12}$ Calculated from Composite Analysis model

${ }^{13}$ Value in parentheses from unsaturated data, DOE, 1997, Table A-7, page A-22.

${ }^{14}$ Average from Water Table aquifer and Barnwell-McBean aquifer

${ }^{15}$ Anisotropy ratio of 4 assumed for Tank 16 annulus model

${ }^{16}$ Freeze and Cherry, 1979, page 55. Assumed mid-range value for sand

${ }^{17}$ DOE, 1997, Table A-6, page A-21. NA: not applicable, NU: not used 


Table A-6. Post-Modeling Worksheet for As-Is Scenario
\begin{tabular}{|l|l|l|l|l|}
\hline Tank 16 Annulus Waste Inventory for Tc-99 & \multicolumn{3}{l}{ AS IS SCENARIO using flux } & \\
\hline Dose Conversion Factors & rem/uCi & L/yr & mrem/rem & Combined \\
\hline (rem/uCi) & $1.30 \mathrm{E}-03$ & 730.5 & 1000 & 949.65 \\
\hline & & & & \\
\hline Total Weight & lbf & 22000 & $\mathrm{~kg}$ & \\
\hline Seepline Water Flux (m^3/yr) & $2.50 \mathrm{E}+01$ & & & \\
\hline Barnwell-McBean Aquifer Split & 0.6 & & & \\
\hline AQUIFER THICKNESS vs. model & 0.666666667 & & & \\
\hline & & & CPHTF-088 & \\
\hline & HTF-086 & HTF-087 & Annulus & \\
\hline & Tank & Annulus & Composite & \\
\hline & Primary & & $4.00 \mathrm{E}-01$ & \\
\hline Sample Concentrations (uCi/g) & $6.20 \mathrm{E}-02$ & $1.34 \mathrm{E}-01$ & $3.99 \mathrm{E}+06$ & \\
\hline Tank Activity (uCi) & $6.19 \mathrm{E}+05$ & $1.34 \mathrm{E}+06$ & & \\
\hline & & & & \\
\hline Seepline Peak Flux & & & 5175 & \\
\hline Years in Future & & & $4.78 \mathrm{E}-05$ & \\
\hline Fractional (uCi per uCi Inventory per year) & & & $1.91 \mathrm{E}+02$ & \\
\hline Absolute (uCi/year) & & & & \\
\hline & & & $7.64 \mathrm{E}+00$ & \\
\hline Seepline Concentration (uCi/m^3) & & & $7.64 \mathrm{E}-03$ & \\
\hline Seepline Concentration (uCi/L) & & & & \\
\hline Seepline Peak Dose (mrem/yr) & & & & \\
\hline Adjusted Seepline Peak Dose (mrem/yr) & & & & \\
\hline & & & & \\
\hline ALLOWABLE RESIDUALS AT 4 mrem/yr & & & & \\
\hline Contaminant Mass (uCi) & & & & \\
\hline Contaminant Concentration (uCi/g) & & & & \\
\hline
\end{tabular}




\section{Table A-7. Post-Modeling Worksheet for Cleaned Scenario}

Tank 16 Annulus Waste Inventory for Tc-99

Dose Conversion Factors

(rem/uCi)

\begin{tabular}{|c|c|c|c|}
\hline & \multicolumn{3}{|c|}{ CLEANED SCENARIO using flux } \\
\hline $\mathrm{rem} / \mathrm{uCi}$ & $\mathrm{L} / \mathrm{yr}$ & mrem/rem & Combined \\
\hline $1.30 \mathrm{E}-03$ & 730.5 & 1000 & 949.65 \\
\hline & & & \\
\hline lbf & 22000 & $\mathrm{~kg}$ & 9979 \\
\hline $2.50 \mathrm{E}+01$ & & & \\
\hline 0.6 & & & \\
\hline 0.6666666 & & & \\
\hline HTF-086 & HTF-087 & CPHTF-088 & \\
\hline Tank & Annulus & Annulus & \\
\hline Interior & & Composite & \\
\hline $6.20 \mathrm{E}-02$ & $1.30 \mathrm{E}-01$ & $4.00 \mathrm{E}-01$ & \\
\hline $6.19 \mathrm{E}+05$ & $1.30 \mathrm{E}+06$ & $3.99 \mathrm{E}+06$ & \\
\hline & & & \\
\hline & & & \\
\hline & & 6173 & \\
\hline & & 5.29E-05 & \\
\hline & & $2.11 \mathrm{E}+01$ & \\
\hline & & & \\
\hline & & $8.46 \mathrm{E}-01$ & \\
\hline & & $8.46 \mathrm{E}-04$ & \\
\hline & & $8.03 \mathrm{E}-01$ & \\
\hline & & $3.21 \mathrm{E}-01$ & \\
\hline & & & \\
\hline & & & \\
\hline & & $4.97 \mathrm{E}+07$ & \\
\hline & & $4.98 \mathrm{E}+00$ & \\
\hline
\end{tabular}


B. T. Butcher, 773-43A

\section{DISTRIBUTION}

T. B. Caldwell, 742-4G

L. B. Collard, 773-43A

J. R. Cook, 773-43A

P. D. d'Entremont, 703-H

T. S. Gutmann, 704-S

T. Hang, 773-43A

G. R. Hannah, Jr., 703-H

L. T. Ling, 703-H

B. A. Martin, $742-4 \mathrm{G}$

T. M. Monahon, 703H

J. P. Morin, 703-H

J. L. Newman, 703-H

E. Saldivar, 742-4G

W. E. Stevens, 773-A

E. L. Wilhite, 773-43A

STI (4)

WPT File 